\title{
Assessment of Livestock Feed Resources and Coping Strategies with Dry Season Feed Scarcity in Mixed Crop-Livestock Farming Systems around the Gilgel Gibe Catchment, Southwest Ethiopia
}

\author{
Belay Duguma ${ }^{1, *}$ and Geert P. J. Janssens ${ }^{2}$ \\ 1 College of Agriculture and Veterinary Medicine, Jimma University, Jimma P.O. Box 307, Ethiopia \\ 2 Department of Nutrition, Genetics and Ethology, Faculty of Veterinary Medicine, Ghent University, \\ 9000 Ghent, Belgium; geert.janssen@ughent.be \\ * Correspondence: duguma2012@gmail.com
}

check for updates

Citation: Duguma, B.; Janssens, G.P.J. Assessment of Livestock Feed Resources and Coping Strategies with Dry Season Feed Scarcity in Mixed Crop-Livestock Farming Systems around the Gilgel Gibe Catchment, Southwest Ethiopia. Sustainability 2021, 13, 10713. https://doi.org/ 10.3390/su131910713

Academic Editors: Laura

L. McKinney, Kelly Zering,

Ahad Pezeshkpoor and Edward L. Kick

Received: 27 May 2021

Accepted: 9 July 2021

Published: 27 September 2021

Publisher's Note: MDPI stays neutral with regard to jurisdictional claims in published maps and institutional affiliations.

Copyright: (c) 2021 by the authors. Licensee MDPI, Basel, Switzerland. This article is an open access article distributed under the terms and conditions of the Creative Commons Attribution (CC BY) license (https:/ / creativecommons.org/licenses/by/ $4.0 /)$.
Abstract: In the current study area, livestock are an integral part of the mixed farming system, and play very important roles as sources of draught power, nutrition, cash income, employment and poverty alleviation. However, feed shortage, especially during the dry season, is the most important constraint to optimal productivity. This study aimed to investigate livestock feed resources and feeding practices, coping strategies with seasonal scarcity, and to identify major constraints to livestock production in a mixed farming system around the Gilgel Gibe catchment, southwest Ethiopia. Data were collected from 342 households using a structured questionnaire. The results showed natural pasture, crop residues, stubble grazing, and roadside grasses were the main feed resources, in that order. None of the respondents practiced improved forage cultivation due to insufficient land and lack of knowledge on forage production and utilization. Free grazing was the most predominant feeding system. Almost all respondents experienced dry season feed scarcity. Conserving crop residues and hay, purchasing roughages, reducing herd size and renting grazing land were the major coping strategies to feed scarcity. The farmers' perceived major constraints to livestock production were feed shortage, animal diseases, and low productivity of local breeds. Institutional, technical and technological interventions are suggested to alleviate the constraints to livestock production in mixed crop-livestock systems in the study area and outside with similar settings.

Keywords: feed scarcity; coping strategies to feed scarcity; feed resources; feeding practices; grazing land degradation; livestock; mixed farming

\section{Introduction}

Agriculture remains the most predominant livelihood activity and source of income of Sub-Saharan African (SSA) rural households [1]. Livestock play multiple important roles for smallholder farmers in Sub-Saharan Africa. They provide animal products for sale or consumption, including manure for crop production, used to invest and save capital, and play an important role in socio-cultural events [2]. The crop-livestock system is the main system at the international scale, and provides around $75 \%$ of dairy, $60 \%$ of meat and up to $50 \%$ of cereals production [3]. The same author also stated two thirds of smallholders in East and Central Africa rely on mixed crop-livestock systems [2].

Agriculture is the backbone of Ethiopia's economy and contributes about $34.1 \%$ to the domestic gross product (GDP), employs some 79\% of the population, accounts for $79 \%$ of foreign earnings, and is the major sources of raw material and capital for investment and market [4]. Over $90 \%$ of agriculture in the country is characterized by mixed croplivestock farming systems. Livestock farming is an integral component of the agriculture and rural livelihood in Ethiopia, contributing about $17-25.3 \%$ of the national gross domestic product (GDP), 39-49\% of agricultural GDP (including the non-monetary values) and over 
$50 \%$ of household incomes [5]. Moreover, livestock contributes to about $12-15 \%$ of the export earnings and provides employment for about $60-70 \%$ of the population [6]. The Intergovernmental Authority on Development (IGAD) showed that the value of the cattle draught power input into arable production is about a quarter $(26.4 \%)$ of the value of annual crop production, and if the value of draught power services is included, the sector contributes up to $\sim 45 \%$ of the agricultural gross domestic product [6].

Ethiopia has the largest livestock population in Africa, with an estimated 65.35 million head of cattle, 39.89 million sheep, 50.50 million goats, 2.11 million horses, 8.98 donkeys, 0.38 and 7.70 million head of camel population, 59.5 million poultry and 5.92 million honey bee hives [7]. These estimates do not include livestock populations in the non-sedentary (nomadic) areas of the Afar and Somali regional states, where they are as primary livelihood activity. Livestock production systems in Ethiopia include extensive (pastoral, agro-pastoral and smallholder mixed farming) and semi-intensive peri-urban and urban production.

In Ethiopia, the livestock population continued to increase, driven by the rapidly increasing demand for livestock products, which is driven by population growth, urbanization, rising per capita incomes and preference for food of animal origin. In rural areas, livestock rearing is the component of rural development contributing to enhanced agricultural productivity and improving rural livelihoods of resource poor farmers through provision of draught power, food (eggs, meat and milk), income, manure for fuel and soil fertility, means of transport, food security, insurance, savings, ritual and other social purposes [8]. Traditional farming practices in the Ethiopian highlands depend on draught oxen for cultivation and threshing [9].

Despite the huge numbers and multiple roles, livestock productivity remained very low in Ethiopia and unable to meet the demands for the rapidly growing population. This is often attributed to various constraints such as feed scarcity, high prevalence of diseases and parasites, low genetic potential of local breeds, inadequate veterinary services, lack of access to credit, land scarcity, and poor management practices across all livestock production systems [10-12]. Among these constraints, poor quality and inadequate quantity of feed supply, especially during the dry season, were identified as the major cause of the low livestock productivity [13]. The major causes for feed shortage are diminishing natural pastures/grazing land, population growth, expansion of cropping at the expense of grazing lands, and expansion of degradable lands, which can no longer support either annual crops and pastures [14]. Therefore, to increase livestock productivity, it is essential to improve the availability of feed resources.

Adequate availability of quality feed is a basic requirement for livestock to perform well. An adequate supply of livestock feed is crucial to the livelihoods of millions of people across the developing world such as smallholders, pastoralists and the large number of landless who depend mainly on common land for grazing [15]. Feed affects livestock productivity, profitability, human food and nutrition security, animal welfare and ethics, and animal and human health [16]. Good quality feed and proper feeding improve livestock productivity, resulting in lower age at first calving and shorter inter-calving interval, thus increasing productive life and profitability, animal immunity, health, welfare, and reproductive performance and enables higher productivity under a given management regimen and contributes to environmental sustainability by converting energy and nutrients from land that is unusable by humans into highly nutritious food $[17,18]$. Therefore, if the food security and living standards are to be improved in the mixed farming systems in Ethiopia, livestock feed supply needs to be improved by alleviating feed constraints facing livestock farmers.

According to CSA [7], the country is endowed with various feed resources having different feed use share, which encompassed natural pasture grazing (54.59\%), crop residues $(31.60 \%)$, hay $(6.85 \%)$, agro-industrial byproducts $(1.53 \%)$, improved feed $(0.31 \%)$ and others like animal byproducts, vegetable and fruit wastes (5.11\%). However, most of these feed resources are low in quality and quantity, adversely affecting livestock productivity [5]. The use of grain-based concentrates for ruminant feeding is little practical due to 
competition with human food and monogastric animals and the high cost of production. Besides, the introduction and adoption of improved forage crops into the farming system has been constrained by the lack of land and forage seeds [13].

In Ethiopia, negative feed balances of 21.5 in average and 48.7 million tonnes DM in bad years were reported for the mixed crop-livestock systems, implying that most animals are fed below their DM requirement of $2.5-3 \%$ of body weight [5]. Increased use of bulule (grain mill leftovers), using crop residues and non-conventional feeds, conserving hay, purchasing green feeds and reducing herd size were used as coping strategies to feed scarcity [19]. Free grazing is reported to be the predominant type of livestock feeding system in most parts of the extensive and smallholder crop-livestock farming areas in Ethiopia $[20,21]$.

The Ethiopian highlands are endangered by severe land degradation [22,23]. This has direct impacts on agricultural productivity, affecting grazing land through loss of soil and decreased soil fertility, thus constituting a major threat to sustainable feed resources [24]. Thus, the increasing livestock population is forced to graze on a decreasing amount of grazing land, which contributes to further land degradation [25], and poorly fed animals characterized by low productivity [24]. The integration of crop and livestock production is considered to be a key pathway to improved productivity, efficiency, and sustainability [26].

In the current study area, thousands of mixed crop-livestock farmers from four districts were evacuated from their farm lands during the filling of the Gilgel Gibe Hydroelectric dam around the Gilgel Gibe catchment, and resettled in vast communal grazing lands. Since then, the resettled communities are faced with various socio-economic problems, including shortage of livestock feed due to human and livestock population growth, leading to diminishing land available for crop and pasture, resulting in land degradation and reduced productivity. Jimma University (JU), in collaboration with the institutional university cooperation (IUC) (IUC-JU) program of the Flemish Interuniversity Council (VLIR-UOS), designed seven multidisciplinary and integrated research projects investigating the impact of the hydroelectric power plant on human and animal health, ecology and agronomy, in order to improve the life quality or food security of local mixed crop-livestock farmers. Livestock health and nutrition was among the seven priority research areas identified and aimed at alleviation of food insecurity and poverty of the local community through improving impacts of diseases and nutrition on livestock productivity. After the resettlement of the local community, feed scarcity has been continued to be one of the most important challenges to livestock production. However, there is a paucity of information on the available feed resources in the current study area. This gap of information is one of the major problems to improve the overall feed supply and productivity of livestock. Therefore, understanding the overall feed resources is of paramount importance to generate an information guide to agricultural extension, feed development stakeholders and policy makers to design appropriate intervention strategies and practices for improving feed supply and serve as a basis for future research. The objective of this study was to assess feed resources, feeding practices, coping strategies with feed scarcity, and to identify the major constraints to livestock production across three altitude regions in smallholder mixed crop-livestock production systems around the Gilgel Gibe catchment, southwest Ethiopia.

\section{Materials and Methods}

\subsection{Study Area}

This study was conducted in mixed crop-livestock farming systems of four districts around the Gilgel Gibe catchment, Jimma zone, Oromia Regional State, southwest Ethiopia (Figure 1). It is situated at $7^{\circ} 47^{\prime} 19.17^{\prime \prime}-7^{\circ} 49^{\prime} 02.50^{\prime \prime} \mathrm{N}$ and $37^{\circ} 13^{\prime} 08.54^{\prime \prime}-37^{\circ} 20^{\prime} 06.31^{\prime \prime} \mathrm{E}$. The altitude ranged from 1600 to $2600 \mathrm{~m}$ asl [27]. In this area, a hydroelectric power plant with adjacent reservoir and dam is operational. The selection of the study area was performed purposely within the context of a multidisciplinary research project with the institutional university cooperation (IUC) and Jimma University (JU) (IUC-JU) program of the Flemish Interuniversity Council (VLIR-UOS) investigating the impact of this hydroelectric power 
plant on human and animal health, ecology and agronomy, in order to improve the life quality of local communities in the four districts. The study area was stratified into three sub regions: low altitude region (LAR, 1600-1800 m above sea level (asl)), medium (MAR, $1801-2000 \mathrm{~m}$ asl) and high (HAR, 2001-2600 m asl). The climate of the area is sub- to humid tropical climate; with an average annual rainfall ranging from 1200 to $2800 \mathrm{~mm}$. The three study areas have a bimodal rainfall pattern, short rain season (March to May) and long rain season (June to September) (10. http:/ / en.wikipedia.org/wiki/Jimma_Zone (accessed on 12 December 2020)). The average annual temperature is $19.5^{\circ} \mathrm{C}$ (http:/ / www. weatherzone.com.au/world/africa/ethio (accessed on 12 December 2020)). The area has slightly undulated to plain terrain features. The major soil type is Nitisols, covering about $90 \%$ of the study area. The catchment is characterized by crop-livestock mixed farming system, in which crops and animals are integrated on the same farm unit. According to the information obtained from Agricultural and Rural Development offices of the study area, barley (Hordeum vulgare L.), maize (Zea mays L.), sorghum (Sorghum bicolor L.), tef (Eragrostis tef (Zucc)Trotter.), wheat (Triticum aestivum L.), and faba bean (Vicia faba L.), field pea (Pisum sativum L.), and haricot bean (Phaseulus vulgaris L.) are the major food crops. Coffee (Coffea arabica L.) and Khat (Catha edulis F.) are the major cash crops. Ensete (Ensete ventricosum Welw.) Cheesman, fruits trees such as avocado (Perea Americana Mill.), mango (Mangifera indica L.), papaya (Carica papaya L.); root crops such as potatoes (Solanum tuberosum L.), sweet potatos (Ipomoea batatas L.) Lam, cassava (Manihot esculenta (cassava)), yam (Dioscorea rotundata) and taro (Colocasia esculenta L.), and vegetables are also grown in considerable amounts for household consumption and local market. Indigenous livestock species included cattle, goats, sheep, equines and chickens, with cattle being the most predominant species.

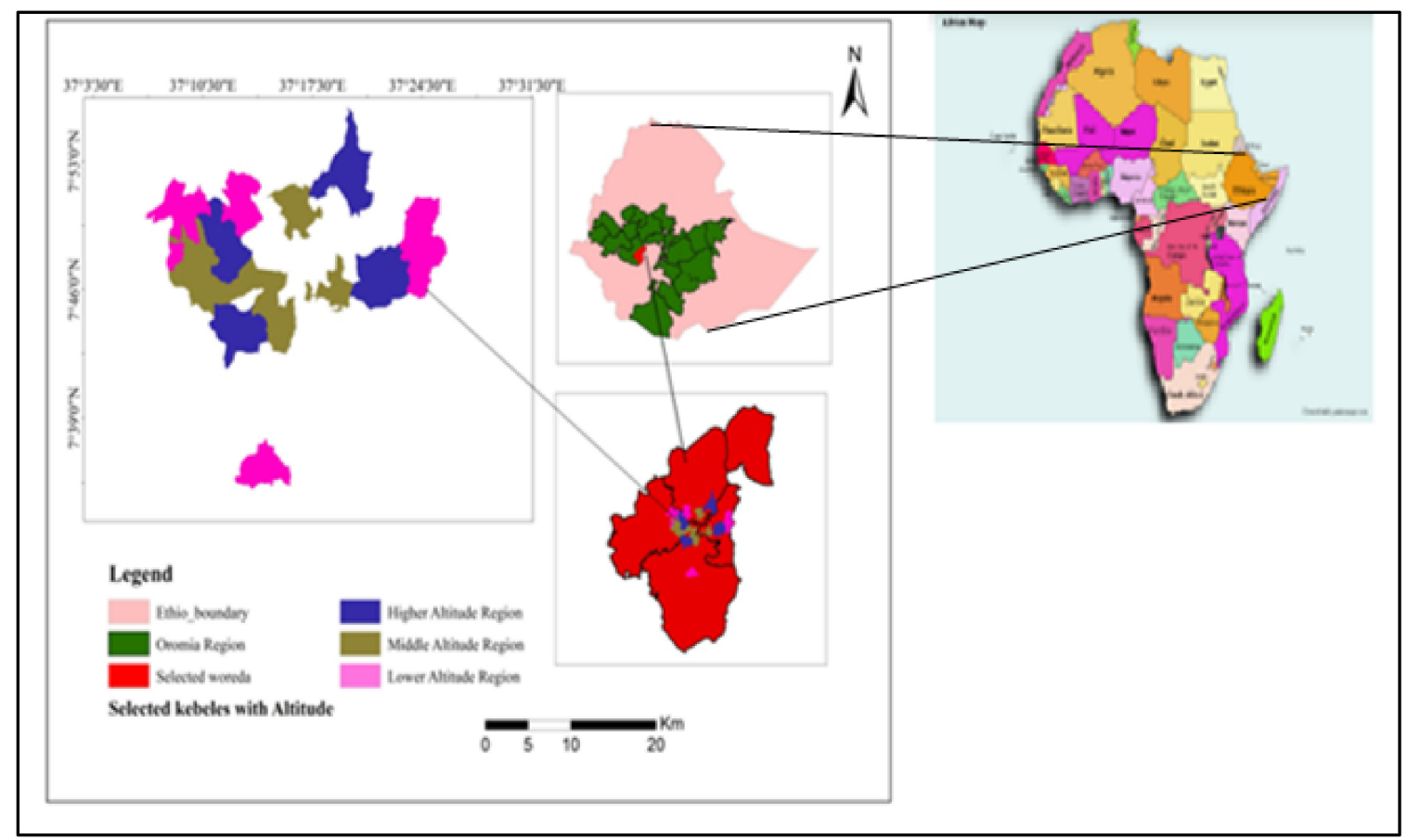

Figure 1. The study area, Gilgel Gibe catchment, southwest Ethiopia.

\subsection{Study Design, Research Design and Sampling Procedure}

The study design was cross-sectional and the research design was both qualitative and quantitative. The sampling method was stratified random sampling [28] based on difference in altitude. A reconnaissance survey was conducted out to have an understanding of the study areas in the four districts and to select representative altitude regions before proceeding to a formal survey. Then, the districts were stratified into three regions (strata) 
based on altitude designated as low, medium and high altitude region, as it is been shown that farming systems, vegetation, soils, mode of life and many other characteristics vary across altitude zones [28-30]. Accordingly, the peasant associations (PAs), which are the lowest administrative units, in the study districts were grouped into three altitude regions. Measurement of boundaries of each altitude stratum was performed using the geographic positioning system (GPS). A list of livestock keeping households was compiled from a list of farmers maintained by farmers' association and agricultural development agent offices, and used as the study population. Subsequently, a total of 342 households (120 in LAR, 120 in MAR and 102 in LHR) were selected using a simple random sampling method.

\subsection{Data Collection}

Both qualitative and quantitative data were collected through face-to-face individual household interviews using semi-structured questionnaire, with open- and close-ended questions. The questionnaire was developed in English, and translated and administered in Afaan Oromo, a language commonly spoken by all respondents. A pre-tested questionnaire was used to collect information from a randomly selected representative sample of 342 smallholder mixed crop-livestock farmers (120 in LAR, 120 in MAR and 102 in HAR) by 12 trained enumerators (local development agents/extension officers) under close supervision of the first author. A single visit multi-subject formal survey method was used for the survey [28]). The questionnaire was used to collect data on: socio-demographic characteristics of respondents (age, educational level, household size, gender, marital status, sources of income, land holding), cattle herd size and structure, reasons for keeping cattle, cattle breeds, trends in livestock population in the last two decades, farmers' perceptions on causes of grass species composition changes, livestock breeding methods, means of acquiring breeding females and bulls, reasons for cattle exits in the year prior to the survey, and feed resources base and feeding systems, feed conservation, practices of supplementary feeding, feed sufficiency and coping strategies with feed scarcity, seasonal calendar of feed resources availability, handling of crop residues, grazing land utilization, management strategies of grazing or pasture land, perceptions on causes of grazing land degradation and its impacts on livestock performance, housing management, water sources and watering frequencies, common diseases of livestock and treatment options, and major constraints to livestock production. To know the overview of cattle production system in the study area, additional research tools such as key informant interviews with experts of Livestock Development and Health Care Agency of the respective districts, informal discussion with elders, community leaders and local livestock production and nutrition agents, personal observations and field notes were also used to augment the questionnaire. Secondary data were obtained from agricultural and rural development offices of the respective districts.

\subsection{Statistical Analysis}

All data were analyzed using the Statistical Package for Social Sciences (SPSS software program, Version 16.0 (SPSS 2007, Inc., Chicago, IL, USA). Quantitative variables (age, family size, herd size, land size, number of wives) were analyzed in one-way ANOVA and the Duncan multiple range was used to separate means for significant differences $(p<0.05)$ between the three altitude regions. Chi-squared $\left(\chi^{2}\right)$ test was used for categorical variables to determine the association amongst the three altitude regions. The analysis included descriptive statistics (percentages and means), cross-tabulations and Pearson Chi-square tests of association.

\section{Results}

\subsection{Socio-Economic Characteristics of the Respondents}

The percentages, given in all the results of this study, indicate the percentages of the respondents interviewed, unless otherwise stated. The socioeconomic characteristics of the respondents included in the current study are presented in Table 1. Results showed that on average, the majority of the respondents were male $(p<0.05)$. The overall average age of 
the respondents was $46.65 \pm 0.50$ years, and respondents in LAR had lower $(p<0.05)$ mean age than that of the others. Average family size was $8.94 \pm 0.17$ persons. The majority of the respondents were illiterate (i.e., do not read and write), and only $13.4 \%$ had primary school education. Land holding was small, with a mean size of $1.95 \pm 0.05$ and $0.17 \pm 0.01$ ha for crops and grazing, respectively (Table 1). The average size of arable land was significantly influenced $(p<0.05)$ by altitude region. Mean number of wives of male respondents was $1.16 \pm 0.00$.

Table 1. Socio-economic characteristics of respondents in cross-sectional survey of 342 smallholder farmers around Gilgel Gibe catchment, southwest Ethiopia.

\begin{tabular}{|c|c|c|c|c|c|}
\hline \multirow{2}{*}{ Parameter } & \multicolumn{4}{|c|}{ TARs } & \multirow{2}{*}{$p$-Value } \\
\hline & LAR & MAR & HAR & Total & \\
\hline Gender (\%) & & & & & * \\
\hline Male & 90.8 & 95.8 & 100 & 95.5 & \\
\hline Female & 9.2 & 4.2 & 0 & 4.5 & \\
\hline Marital status (\%) & & & & & NS \\
\hline Married & 96.7 & 97.5 & 100 & 98.1 & \\
\hline Single & 3.3 & 2.5 & 0 & 1.9 & \\
\hline Education level (\%) & & & & & NS \\
\hline Primary school & 15.8 & 11.7 & 12.7 & 13.4 & \\
\hline Illiterate & 84.2 & 88.3 & 87.3 & 86.6 & \\
\hline & & Mean $( \pm S E)$ & & & \\
\hline Age (years) & $44.71 \pm 1.12^{\mathrm{a}}$ & $48.61 \pm 0.65^{b}$ & $46.64 \pm 0.66^{\mathrm{ab}}$ & $46.65 \pm 0.50$ & * \\
\hline Family size (number) & $8.83 \pm 0.32$ & $8.94 \pm 0.23$ & $6.05 \pm 0.29$ & $8.94 \pm 0.17$ & NS \\
\hline Number of wives & $1.13 \pm 0.03$ & $1.8 \pm 0.04$ & $1.16 \pm 0.04$ & $1.16 \pm 0.00$ & NS \\
\hline Land holding (ha) & & & & & \\
\hline Arable/crop land & $1.78 \pm 0.07^{\mathrm{a}}$ & $2.01 \pm 0.09^{\mathrm{a}}$ & $2.07 \pm 0.10^{b}$ & $1.95 \pm 0.05$ & $*$ \\
\hline Grazing land & $0.15 \pm 0.02$ & $0.16 \pm 0.03$ & $0.20 \pm 0.04$ & $0.17 \pm 0.01$ & NS \\
\hline
\end{tabular}

TARs $=$ Three altitude regions; ${ }^{*}=$ significant; within rows, means $( \pm$ SE) followed by different letters indicates significant difference $(p<0.05) ;{ }^{*}=$ significant; NS, non-significant; SE, standard error.

\subsection{Farming Systems}

From the results of the study, the study area can be characterized by mixed croplivestock production systems. Cattle were the dominant livestock species kept by the respondents. Barley (Hordeum vulgare L.), maize (Zea mays L.), sorghum (Sorghum bicolo $r$ L.), tef (Eragrostis tef (Zucc) Trotter.), wheat (Triticum aestivum L.), and faba bean (Vicia faba L.), field pea (Pisum sativum L.), and haricot bean (Phaseulus vulgaris L.) are the major food crops. Coffee (Coffea Arabica L.) and Khat (Catha edulis F.) are the major cash crops. Enset (Ensete ventricosum Welw.) Cheesman, fruits trees such as avocado (Perea Americana L.), mango (Mangifera indica L.), papaya (Carica papaya L.), root crops such as potatoes (Solanum tuberosum L.), sweet potatoes (Ipomoea batatas L.) Lam, cassava (Manihot esculenta (cassava)), yam (Dioscorea rotundata) and taro (Colocasia esculenta L.), and vegetables are also grown in considerable amount. Indigenous livestock species included cattle, goats, sheep, equines and chicken, cattle being the major species. Respondents stated crops as the major farming activity and main source of household livelihood, and livestock is the second most important source of income. Thus, both crop and livestock production are vital forms of protection against food insecurity. Livestock provided draught power, manure and urine (nutrient cycling) for the maintenance of soil fertility and sale of livestock provided cash for purchasing inputs for crop production, while crops provided a range of residues, grain and grain products for feeding livestock, and sale of crops provided cash for purchasing animals. Thus, crops and livestock had a significant contribution to the livelihoods of the smallholder farmers in the area. In general, the farming systems can be classified into three: barley-wheat-pulses-livestock system in the HAR, maize-wheat-teff-livestock system in the MAR and maize-sorghum-teff-livestock system in the LAR. 


\subsection{Herd Size and Reasons for Keeping Cattle}

Cattle herd size per household (HH), reason for animal exits in the last 12 months prior to the survey, and reasons for keeping cattle are shown in Table 2. Cattle are the dominant livestock species kept by the respondents. The mean cattle herd size was $6.8 \pm 1.1$. The herds were dominated by breeding females $(78.7 \%)$. The average herd size of male cattle was significantly $(p<0.05)$ higher in HAR attributed to intensive crop cultivation and the need for more oxen for draught power. All cattle $(100 \%)$ reared were the local zebu breed. The reasons for cattle exits in the last 12 months significantly varied $(p<0.05)$ across the TAR. The main reasons for cattle exits, in decreasing order, were mortality, gifts, and sales (Table 2). The majority of the respondents primarily acquired their breeding cows and bulls through birth within their own herd, whereas few of them were acquired through purchases (Table 2). The main reasons for keeping cattle were for draught power, breeding, milk and meat, and a source of cash income.

Table 2. Mean cattle herd size per $\mathrm{HH}$, animal exits in the last 12 months, and reasons for keeping cattle in cross-sectional survey of 342 households around the Gilgel Gibe catchment, southwest Ethiopia.

\begin{tabular}{|c|c|c|c|c|c|}
\hline \multirow{2}{*}{ Parameter } & \multicolumn{4}{|c|}{ TARs } & \multirow{2}{*}{$p$-Value } \\
\hline & LAR & MAR & HAR & Overall Mean & \\
\hline \multicolumn{6}{|l|}{ Herd size (mean $\pm \mathrm{SE}$ ) } \\
\hline Male cattle (number) & $1.99 \pm 0.12^{\mathrm{a}}$ & $0.98 \pm 0.13^{b}$ & $1.36 \pm 0.16^{\mathrm{c}}$ & $1.45 \pm 0.08$ & * \\
\hline Female cattle (number) & $5.60 \pm 0.25$ & $5.24 \pm 0.23$ & $5.2 \pm 0.26$ & $5.35 \pm 0.14$ & NS \\
\hline \multicolumn{6}{|l|}{$\begin{array}{l}\text { Cattle exits in the last } 12 \text { months } \\
\text { prior to the survey (mean } \pm \mathrm{SE} \text { ) }\end{array}$} \\
\hline Male cattle died & $0.38 \pm 0.07^{\mathrm{a}}$ & $0.32 \pm 0.50^{\mathrm{a}}$ & $0.08 \pm 0.03^{b}$ & $0.27 \pm 0.03$ & * \\
\hline Female cattle died & $0.68 \pm 0.08^{\mathrm{a}}$ & $0.19 \pm 0.06^{b}$ & $0.04 \pm 0.02^{b}$ & $0.32 \pm 0.04$ & * \\
\hline Male cattle sold & $0.30 \pm 0.06^{\mathrm{a}}$ & $0.38 \pm 0.07^{\mathrm{a}}$ & $0.12 \pm 0.05^{b}$ & $0.27 \pm 0.04$ & * \\
\hline Female cattle sold & $0.39 \pm 0.08^{a}$ & $0.12 \pm 0.05^{b c}$ & $0^{c}$ & $0.18 \pm 0.03$ & * \\
\hline Male cattle gifted & $0.29 \pm 0.06^{\mathrm{a}}$ & $0.12 \pm 0.04^{b c}$ & $0.20 \pm 0.01^{\mathrm{c}}$ & $0.15 \pm 0.02$ & * \\
\hline Female cattle gifted & $0.33 \pm 0.07^{\mathrm{a}}$ & $0.60 \pm 0.09 \mathrm{~b}$ & $0.05 \pm 0.03^{c}$ & $0.34 \pm 0.04$ & * \\
\hline \multicolumn{6}{|l|}{ Cattle breed raised $(\%)$} \\
\hline Local breed & 100 & 100 & 100 & 100 & \\
\hline $\begin{array}{l}\text { Means of acquiring breeding } \\
\text { females }(\%)\end{array}$ & & & & & 0.089 \\
\hline Bred on farm & 98.3 & 92.5 & 93.0 & 94.6 & \\
\hline Purchased & 1.7 & 7.5 & 6.9 & 5.4 & \\
\hline Means of acquiring breeding bulls & & & & & 0.443 \\
\hline Born within own herd & 86.8 & 91.7 & 88.2 & 88.9 & \\
\hline Purchased & 13.1 & 8.3 & 11.8 & 11.1 & \\
\hline Reasons for keeping cattle (\%) & & & & & NS \\
\hline Draught power, breeding and milk & 98.3 & 95 & 91.2 & 94.8 & \\
\hline Income source & 1.7 & 5 & 8.8 & 5.2 & \\
\hline
\end{tabular}

Within rows, means $\left( \pm\right.$ SE) followed by different letters indicates significant difference $(p<0.05) ;{ }^{*}=$ significant; NS, non-significant; SE, standard error.

\subsection{Perceptions on Livestock Population Trends}

Farmers' perceptions on livestock population trends over the last two decades varied significantly $(p<0.001)$ across the TARs. In total, $56.7 \%$ of the respondents indicated an increasing trend in the total livestock population over the last two decades. The increase was attributed to the increased demand for draught power and milk $(50.8 \%, 9.2 \%$ and $32.5 \%$ of the respondents in LAR, MAR and HAR, respectively) and cash income $(18.3 \%, 20 \%$ and $42.2 \%$ respondents in LAR, MAR and HAR, respectively), whereas 30.8, 70.8 and $25.5 \%$ of the respondents in the LAR, MAR and HAR reported a declining trend, respectively, with medium altitude having most farmers indicating a decreasing trend, and attributed it to shortage of feed and insufficient land $(25.8,61.7$ and $14.7 \%$ respondents in LAR, MAR and HAR, respectively) and livestock mortality (5\%, $9.2 \%$ and $10.8 \%$ respondents in LAR, MAR and HAR, respectively). About 95, 89.2 and $93.1 \%$ of respondents in LAR, MAR 
and HAR, respectively, reported a change in livestock composition, and major changes have been observed in cattle $(74.2,85.8$ and $81.4 \%$ respondents in LAR, MAR and HAR, respectively), followed by sheep and goats $(9.2,3.3$ and $11.8 \%$ in LAR, MAR and HAR, respectively) and equines (11.7\% in LAR). The reason for the change was related to scarcity of feed resources. While 5, 10.8 and 6.9\% respondents in LAR, MAR and HAR, respectively, indicated there has been no change in their livestock composition over the last two decades due to balanced exits and replacements.

\subsection{Feed Resources and Feeding Practices}

There was a significant difference among the different types of livestock feed resources used. The main feed resources available in the study area, in order of importance, include natural pasture, crop residues, aftermath/stubble grazing and roadside fodder (Table 3 ). Moreover, non-conventional feeds, such as Ensete ventricosum (Welw.) Cheesman and banana (Musa accuminata) leaves and pseudo-stems, sugarcane (Saccharum officinarum) tops, sweet potato (Ipomoea batatus L.) vines, and foliage of indigenous browse trees and shrubs were also reported to be important sources of feed and have a potential to increase feed availability during the dry season. Natural pasture was reported to be the most important feed resource during the long rainy season of high grass growth from June to September; however, its availability and quality experience rapid decline with maturity as dry season advanced, and livestock are frequently exposed to long periods of natural pasture scarcity in the dry seasons, resulting in low productive and reproductive performance and increased vulnerability to diseases and parasites.

Table 3. Perceptions on trends in livestock population and composition over time in cross-sectional survey of 342 households around the Gilgel Gibe catchment, southwest Ethiopia.

\begin{tabular}{|c|c|c|c|c|c|}
\hline \multirow{2}{*}{ Parameter } & \multicolumn{4}{|c|}{ ATRs } & \multirow{2}{*}{$p$-Value } \\
\hline & LAR & MAR & HAR & Mean & \\
\hline Trend in livestock population over time & & & & & 0.000 \\
\hline Increasing & 69.2 & 29.2 & 74.5 & 57.6 & \\
\hline Declining & 30.8 & 70.8 & 25.5 & 42.4 & \\
\hline Reasons for increasing & & & & & 0.000 \\
\hline Increased demand for food and services & 50.8 & 9.2 & 32.3 & 30.8 & \\
\hline Income generation & 18.3 & 20.0 & 42.2 & 26.8 & \\
\hline Reasons for declining & & & & & 0.000 \\
\hline Feed and land scarcity & 25.8 & 61.7 & 14.7 & 34.1 & \\
\hline Diseases & 5.0 & 9.2 & 10.8 & 8.3 & \\
\hline $\begin{array}{l}\text { Change in livestock composition over } \\
\text { time }\end{array}$ & & & & & 0.000 \\
\hline Yes & 95.0 & 89.2 & 93.1 & 92.4 & \\
\hline No & 5 & 10.8 & 6.9 & 7.6 & \\
\hline Change occurred in & & & & & 0.000 \\
\hline Cattle & 74.2 & 85.8 & 81.4 & 80.5 & \\
\hline Sheep and goats & 9.2 & 3.3 & 11.8 & 8.0 & \\
\hline Equines & 11.7 & 0 & 0 & 3.9 & \\
\hline No change & 5.0 & 10.8 & 6.9 & 7.6 & \\
\hline
\end{tabular}

Crop residues derived mainly from cereal crops such as barely, maize, sorghum, tef and wheat, and to a limited extent from legume crops residues, i.e., faba beans, field peas and haricot beans were the most important crop residues used in addressing dry season feed scarcity. However, not all the crop residues produced were used by animals due to their alternative uses as fuel, mulch, construction, and losses in situ. The inefficient use of crop residues as animal feed was attributed to labor shortages for collection, transportation, and lack of storage facilities and proper technologies. From our field observation, the majority of the maize and sorghum stovers were left in the crop land after harvesting the cob, resulting in substantial losses and decline in the nutrient content. None of the 
respondents reported supplementing agro-industrial by-products to their livestock due to unavailability.

\subsection{Feeding Practices}

Free grazing was the most predominantly used feeding system (Table 4); however, animals herded during the rainy season to restrict their free movement to prevent damaging planted crop. However, after crop harvest all animals are set free to graze on natural pasture, crop stubble, fallow land, and forest areas. Few respondents reported tethering of their animals on private grazing lands during the cropping season due to labor constraints for herding.

Table 4. Major livestock feed resources and feeding practices in cross-sectional survey of 342 household around the Gilgel Gibe catchment, southwest Ethiopia.

\begin{tabular}{|c|c|c|c|c|c|}
\hline \multirow{2}{*}{ Feed Resources and Feeding System } & \multicolumn{4}{|c|}{ TARs } & \multirow{2}{*}{$p$-Value } \\
\hline & LAR & MAR & HAR & Mean & \\
\hline Feed resources (\%) & & & & & 0.005 \\
\hline Natural pasture & 71.7 & 77.5 & 82.3 & 77.2 & \\
\hline Crop residues & 11.7 & 10 & 11.7 & 11.1 & \\
\hline Stubble grazing & 13.3 & 5 & 0 & 6.1 & \\
\hline Roadside fodder & 3.3 & 7.5 & 5.9 & 5.6 & \\
\hline Feeding system (\%) & & & & & 0.206 \\
\hline Free grazing & 91.7 & 95 & 97.1 & 94.6 & \\
\hline Tethering & 8.3 & 5 & 2.9 & 5.4 & \\
\hline
\end{tabular}

\subsection{Perceptions on Feed Sufficiency and Forage Cultivation}

Almost all respondents stated that the available feed resources were not adequate, particularly in the dry season (Table 5), whereas all respondents interviewed indicated adequate availability of feed resources during the long rainy seasons (June to September). None of the respondents reported the adoption of improved forage cultivation. The principal reasons for non-adoption of the technology were insufficient land and lack of information on how to establish, manage, conserve and utilize improved forages due to weak extension services (Table 5). Hence, raising farmers' awareness about improved forages should be the first step towards uptake of the technology. Overall, more than onethird of respondents indicated future scope to integrate improved multipurpose fodder trees and shrubs (MPTS) into their farming system (Table 5). The lack of growing MPTS was attributed to lack of awareness about their multipurpose importance as sources of feed (mineral and protein), food, improve soil fertility and fuel wood. More than one-third of interviewees stated that the available indigenous fodder trees were adequate, whereas that of indigenous shrubs were inadequate.

Table 5. Perceptions on feed resources adequacy and practice of improved forage production in cross-sectional survey of 342 smallholder farmers around the Gilgel Gibe catchment, southwest Ethiopia.

\begin{tabular}{cccccc}
\hline Parameter & \multicolumn{3}{c}{ TARs } & \multicolumn{1}{c}{$p$-Value } \\
\cline { 2 - 5 } & LAR & MAR & HAR & Mean & 0.724 \\
General feed availability (\%) & & & & 7.6 & \\
Adequate & 9.2 & 6.7 & 6.9 & 92.4 & 0.365 \\
Inadequate & 93.3 & 93.3 & 93.1 & 9.5 & 90.5 \\
Dry season feed availability & & & 12.7 & 87.3 & \\
Adequate & 8.3 & 92.5 & & & \\
Inadequate & 91.7 & &
\end{tabular}


Table 5. Cont

\begin{tabular}{|c|c|c|c|c|c|}
\hline \multirow{2}{*}{ Parameter } & \multicolumn{4}{|c|}{ TARs } & \multirow{2}{*}{$p$-Value } \\
\hline & LAR & MAR & HAR & Mean & \\
\hline \multicolumn{6}{|l|}{ Wet season feed availability } \\
\hline Adequate & 100 & 100 & 100 & 100 & \\
\hline Inadequate & 0 & 0 & 0 & 0 & \\
\hline \multicolumn{6}{|l|}{ Practice of improved forage cultivation } \\
\hline Yes & 0 & 0 & 0 & 0 & \\
\hline No & 100 & 100 & 100 & 100 & \\
\hline $\begin{array}{l}\text { Reasons for not practicing forage } \\
\text { cultivation }\end{array}$ & & & & & 0.929 \\
\hline Land scarcity & 90.8 & 91.7 & 90.2 & 90.9 & \\
\hline Lack of awareness & 9.2 & 8.3 & 9.8 & 9.1 & \\
\hline $\begin{array}{l}\text { Scope for adopting improved fodder } \\
\text { trees and shrubs }\end{array}$ & & & & & 0.000 \\
\hline Yes & 20 & 41.7 & 44.1 & 35.3 & \\
\hline No & 80 & 58.3 & 55.9 & 64.7 & \\
\hline $\begin{array}{l}\text { Availability of indigenous fodder trees } \\
\text { and shrubs }\end{array}$ & & & & & 0.000 \\
\hline Abundant & 5 & 42.5 & 60.8 & 36.1 & \\
\hline Moderate & 5.8 & 32.5 & 8.8 & 15.7 & \\
\hline Low & 89.2 & 14.2 & 4.9 & 36.1 & \\
\hline Don't know & 0 & 10.8 & 25.5 & 12.1 & \\
\hline
\end{tabular}

\subsection{Coping Strategies with Dry Season Feed Scarcity}

The findings of this study have shown that almost all the respondents experienced acute scarcity of feed supply during the dry season (Table 6). In decreasing order of importance, conserving crop residues and hay, purchasing roughages, reducing herd size, and renting grazing land were the main coping strategies to feed scarcity adopted by the farmers. Perceived indicators of feed scarcity on livestock performance included poor productivity, increased mortalities, and slow growth rate and delayed puberty of young animals (Table 6).

Table 6. Farmers' perceptions on feed scarcity during dry seasons, coping mechanisms and impacts on cattle in crosssectional survey of 342 smallholder farmers around the Gilgel Gibe catchment, southwest Ethiopia.

\begin{tabular}{|c|c|c|c|c|c|}
\hline \multirow{2}{*}{ Parameter } & \multicolumn{4}{|c|}{ TARs } & \multirow{2}{*}{$p$-Value } \\
\hline & LAR & MAR & HAR & Mean & \\
\hline \multicolumn{6}{|l|}{ Do you experience feed shortage during dry seasons } \\
\hline Yes & 100 & 100 & 100 & 100 & \\
\hline No & 0 & 0 & 0 & 0 & \\
\hline Coping strategies with feed scarcity & & & & & 0.000 \\
\hline Conserving crop residues \& hay & 75.8 & 90 & 92.2 & 86.0 & \\
\hline Purchasing roughages & 12.5 & 3.3 & 0 & 5.2 & \\
\hline Reducing the herd size & 1.7 & 4.2 & 7.8 & 4.6 & \\
\hline Renting grazing land & 10 & 2.5 & 0 & 4.2 & \\
\hline Perceived impacts of feed shortage on cattle during dry season & & & & & 0.134 \\
\hline Poor performance & 78.3 & 85.8 & 86.4 & 83.5 & \\
\hline Increased mortalities & 13.3 & 5 & 5.8 & 8.0 & \\
\hline Poor growth rate and delayed puberty in young stock & 8.3 & 9.2 & 7.8 & 8.4 & \\
\hline
\end{tabular}

\subsection{Feed Conservation Practices}

All the respondents reported practicing feed conservation to reduce the problem of feed supply in the dry season (Table 7). There was no difference $(p=0.716)$ in types of feeds conserved across the TARs. On average, 93.9\% (92.5, 95 and $94.1 \%$ of respondents in LAR, MAR and HAR, respectively) conserved crop residues, whereas $6.1 \%(7.5,5$ and $5.8 \%$ 
respondents in LAR, MAR and HAR, respectively) conserved native grass hay. There was a significant difference $(p<0.05)$ between seasons of using conserved feeds. On average, $95.2 \%$ (90, 96.7 and $99 \%$ of respondents in LAR, MAR and HAR, respectively) used conserved feeds during the dry season, whereas $4 / 8 \%$ (10, 3.3 and $1 \%$ of respondents in LAR, MAR and HAR, respectively) used conserved feeds during the wet season. Supplementation of conserved feeds to animals was similar $(p=0.135)$ across the TARs. On average, $85.3 \%$ ( 85,90 and $80.4 \%$ respondents in LAR, MAR and HAR, respectively) fed conserved feeds primarily to milking cows and fattening animals, whereas $11.2 \%(11.7,9.2$ and $12.7 \%$ respondents in LAR, MAR and HAR, respectively) gave feeding priority to draught oxen, and the rest $3.7 \%$ (3.3, 0.8 and $6.7 \%$ respondents in LAR, MAR and HAR, respectively) fed conserved feeds to all types of animals. There was significant difference $(p<0.05)$ in methods of processing crop residues before feeding. On average, $95.9 \%(99.2,97.5$ and $91.2 \%$ respondents in LAR, MAR and HAR, respectively) reported chopping crop residues before feeding to animals, whereas $4.1 \%(0.8,2.5$ and $8.8 \%$ respondents in LAR, MAR and HAR, respectively) mixed with other feeds before feeding.

Table 7. Practice of feed conservation (\%), time of use, and feeding priority in cross-sectional survey of 342 smallholder farmers around Gilgel Gibe hydropower dam in southwest Ethiopia.

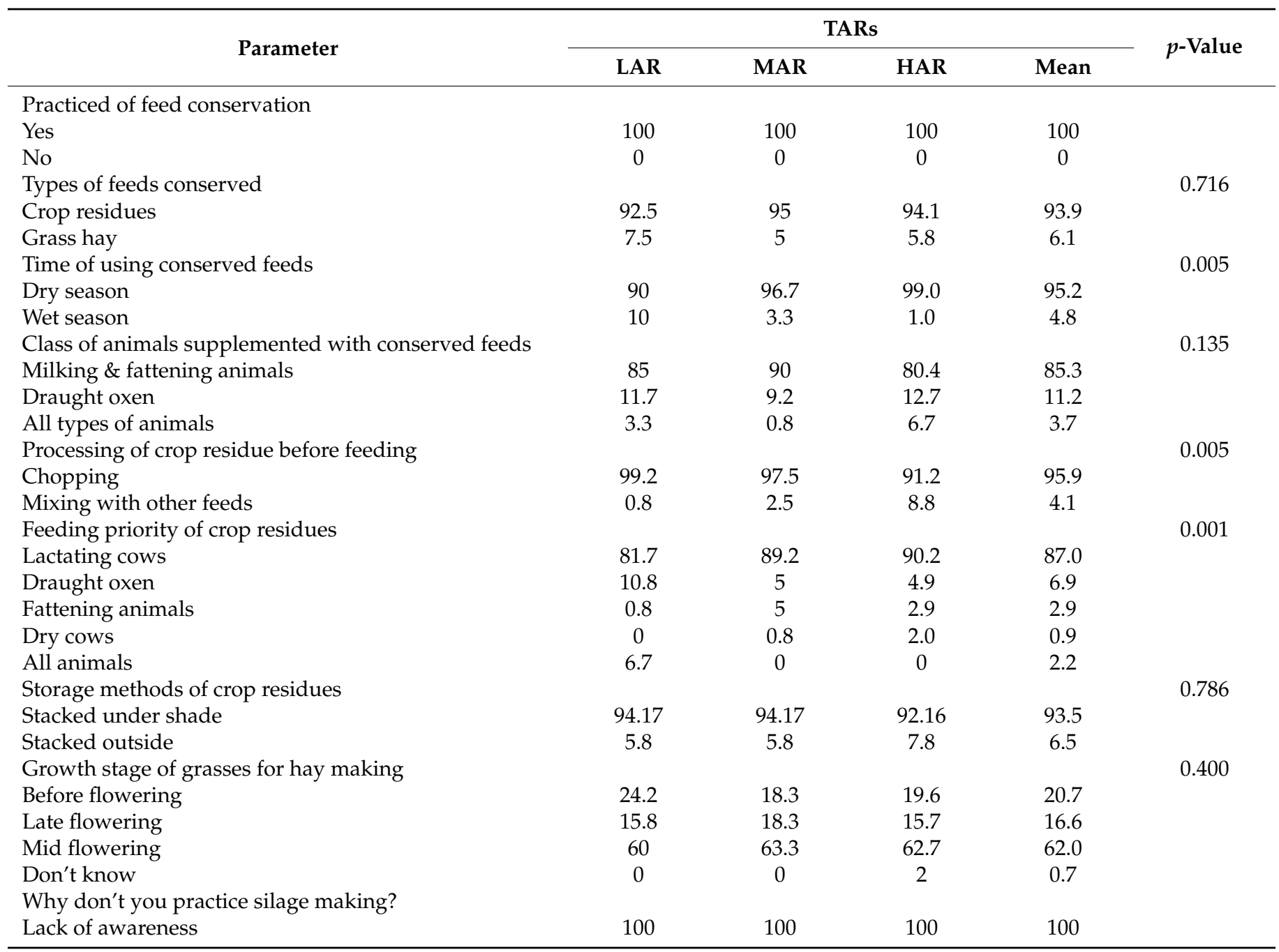

There was a significant difference $(p<0.05)$ in feeding priority of crop residues to animals. On average, $87 \%(81.7,89.2$ and $90.2 \%$ respondents in LAR, MAR and HAR, respectively) gave first feeding priority to lactating cows, $6.9 \%(10.8,5$ and $4.9 \%$ respondents in LAR, MAR and HAR, respectively) to draught oxen, $2.9 \%(0.8,5$ and $2.9 \%$ respondents in 
LAR, MAR and HAR, respectively) to fattening oxen, $2.2 \%$ (6.7\% respondents in LAR) to all animals, and $0.9 \%$ (0.8 and $2 \%$ respondents in MAR and HAR, respectively) for dry cows.

Methods of crop residue storage did not differ $(p=0.786)$. On average, $93.5 \%(94.2$, 94.2 and $92.2 \%$ respondents in LAR, MAR and HAR, respectively) stored crop residues under their sheds, whereas 6.5\% (5.8, 5.8 and 7.8\% respondents in LAR, MAR and HAR, respectively) stored in open air, and this could lead to loss in quantity and nutritive value, and wastage due to decomposition.

The growth stage of grasses for hay making did not differ $(p=0.400)$. On average, $62 \%(60,63.3$ and $62.7 \%$ respondents in LAR, MAR and HAR, respectively) make hay at the mid-flowering stage of grasses, 20.7\% (24.2, 18.3 and 19.6\% respondents in LAR, MAR and HAR, respectively) before flowering, 16.6\% (15.8, 18.3 and 15.7\% respondents in LAR, MAR and HAR, respectively) at late flowering, and $0.7 \%$ ( $2 \%$ respondents in HAR) did not know the maturity stage of grasses for hay making. None of the respondents had information about silage and silage-making methods.

\subsection{Feeding Calendar and Seasonal Availability of Feed Resources}

The pattern of feed resources availability was influenced by seasonal variation (Table 8). Natural pasture was available in varying proportions at all altitude regions almost yearround. However, it is more availability in the rainy season (June to September) and critically declines in both quality and availability during the dry season. During the dry season (October to May), crop residues take up the highest importance, whereas stubble grazing was more available in the dry season (December to April) depending on the type and intensity of crops cultivated at each altitude region. Non-conventional feeds such as Enset (Ensete ventricosum Welw.) Cheesman and banana (Musa accuminata) leaves and pseudostems, sugarcane (Saccharum officinarum) tops, sweet potato (Ipomoea batatus L.) vines, and indigenous browse trees and shrubs are available year round and mainly used in the dry season. This information of the seasonal variation in availability of feed resources is important for future technical interventions to ensure feed availability to seasonal fluctuations.

Table 8. Seasonal feed resources availability in cross-sectional survey of 342 smallholder farmers around the Gilgel Gibe catchment, southwest Ethiopia.

\begin{tabular}{cccc}
\hline Feeding Calendar & Type of Feed & Frequency & Percentage \\
\hline January-December & Natural pasture & 342 & 100 \\
January-May & Hay & 13 & 3.8 \\
February-May & Hay & 192 & 56.1 \\
December-March & Crop residue & 22 & 6.4 \\
December-May & Crop residue & 306 & 89.5 \\
December-March & Stubble grazing & 303 & 88.6 \\
December-April & Stubble grazing & 39 & 11.4 \\
January-December & Non-conventional feeds & 342 & 100 \\
\hline
\end{tabular}

\subsection{Practice of Supplementary Feeding}

All the respondents reported providing whatever available supplementary feeds to their animals (Table 9). There was a highly significant difference $(p<0.01)$ between types of supplementary feeds used. On average, 83.8\% (81.7, 77.5 and $92.2 \%$ respondents in LAR, MAR and HAR, respectively) supplemented household leftovers, $7.8 \%$ (7.5, 10 and $5.9 \%$ respondents in LAR, MAR and HAR, respectively) grain shorts, 5.6\% (7.5, 7.5 and 2\% respondents in LAR, MAR and HAR, respectively) green grass, 2.8 (3.3 and 5\% respondents in LAR and MAR, respectively) cereal grain, and $100 \%$ respondents in LAR, MAR and HAR, respectively, supplemented with common salt. Reasons for supplementary feeding did not differ $(p=0.453)$. On average, $82.7 \%(81.7,84.2$ and $82.3 \%$ respondents in LAR, MAR and HAR, respectively) provided supplementary feeding to increase milk yield and draught power, $16.4 \%(15.8,15.8$ and $17.6 \%$ respondents in LAR, MAR and HAR, respectively) to shorten fattening period and to increase milk yield and draught power, 
$0.6 \%$ (1.7\% respondents in LAR) to increase milk yield, and $0.3 \%$ ( 0.8 respondent in LAR) to maintain pregnancy.

Table 9. Types of supplementary feeds, reasons for supplementation and feeding priority in cross-sectional survey of 342 smallholder cattle farmers around Gilgel Gibe hydropower dam in southwest Ethiopia.

\begin{tabular}{|c|c|c|c|c|c|}
\hline \multirow{2}{*}{ Parameter } & \multicolumn{4}{|c|}{ TARs } & \multirow{2}{*}{$p$-Value } \\
\hline & LAR & MAR & HAR & Mean & \\
\hline \multicolumn{6}{|l|}{ Provision of supplementary feed } \\
\hline Yes & 100 & 100 & 100 & 100 & \\
\hline Types of feed supplements (\%) & & & & & 0.080 \\
\hline Household leftovers & 81.7 & 77.5 & 92.2 & 83.8 & \\
\hline Cut green grasses & 7.5 & 7.5 & 2.0 & 5.6 & \\
\hline Grain shorts & 7.5 & 10 & 5.9 & 7.8 & \\
\hline Cereal grains & 3.3 & 5 & 0 & 2.8 & \\
\hline Common salt & 100 & 100 & 1000 & 100 & \\
\hline Reason for supplementation (\%) & & & & & 0.453 \\
\hline Milk yield \& draught power & 81.7 & 84.2 & 82.3 & 82.7 & \\
\hline Pregnancy & 0.8 & 0 & 0 & 0.3 & \\
\hline Fattening, milk yield \& draught work & 15.8 & 15.8 & 17.6 & 16.4 & \\
\hline Milk yield & 1.7 & 0 & 0 & 0.6 & \\
\hline \multicolumn{6}{|l|}{ Do you supplement oxen (\%) } \\
\hline Yes & 100 & 100 & 100 & 100 & \\
\hline Type of supplements provided to oxen (\%) & & & & & 0.727 \\
\hline Grain mill shorts & 20 & 15 & 15.7 & 16.9 & \\
\hline Lopped browse tree leaves & 22.5 & 21.7 & 18.6 & 20.9 & \\
\hline Household leftovers & 10.8 & 15 & 14.7 & 13.5 & \\
\hline Cereal grains & 15 & 14.2 & 12.7 & 14.0 & \\
\hline Salt & 0.8 & 0 & 0 & 0.3 & \\
\hline Salt \& grass hay & 0.8 & 0 & 0 & 0.3 & \\
\hline Salt & 22.5 & 30 & 33.3 & 28.6 & \\
\hline Crop residues & 7.5 & 4.2 & 4.9 & 5.5 & \\
\hline Frequency of salt supplementation (\%) & & & & & 0.072 \\
\hline Once monthly & 66.7 & 76.7 & 74.5 & 72.6 & \\
\hline Ad libitum & 11.7 & 14.2 & 16.7 & 14.2 & \\
\hline Seasonally & 9.2 & 4.2 & 4.9 & 6.1 & \\
\hline Weekly & 12.5 & 5 & 3.9 & 7.1 & \\
\hline \multicolumn{6}{|l|}{ Benefits of salt supplementation (\%) } \\
\hline Short fattening period & 0.8 & 1.7 & 2.9 & 1.8 & 0.587 \\
\hline Improves growth, fertility and milk yield & 89.2 & 94.2 & 92.2 & 91.8 & \\
\hline Increase milk yield and body condition & 8.3 & 4.2 & 4.9 & 5.8 & \\
\hline Increase milk yield & 0.8 & 0 & 0 & 0.3 & \\
\hline Improve fertility & 0.8 & 0 & 0 & 0.3 & \\
\hline \multicolumn{6}{|l|}{ Do you supplement AIBP (\%) } \\
\hline No & 100 & 100 & 100 & 100 & \\
\hline Reasons for not using concentrate (\%) & & & & & 0.691 \\
\hline High cost & 90 & 88.3 & 88.2 & 88.8 & \\
\hline Lack of access & 4.2 & 5 & 7.8 & 5.7 & \\
\hline Lack of awareness & 5.8 & 6.7 & 3.9 & 5.5 & \\
\hline
\end{tabular}

There was no difference $(p=0.727)$ in feed types used to supplement draught oxen (Table 9). Salt (22.5, 30 and 33.3\% respondents in LAR, MAR and HAR, respectively), leaves of indigenous fodder trees and shrubs $(22.5,21.7$ and $18.6 \%$ respondents in LAR, MAR and HAR, respectively), grain mill shorts (20, 15 and $15.7 \%$ respondents in LAR, MAR and HAR, respectively), cereal grain $(15,14.2$ and $12.7 \%$ respondents in LAR, MAR and HAR, respectively), household leftovers $(10.8,15$ and $14.7 \%$ respondents in LAR, MAR and HAR, respectively), crop residues (7.5, 4.2 and $4.9 \%$ respondents in LAR, MAR and HAR, respectively), and salt ( $0.8 \%$ in LAR), and salt and hay ( $0.8 \%$ in LAR) were feeds used to supplement draught oxen, respectively. Frequency of salt supplementation did not differ 
$(p=0.072)$. On average, $72.6 \%(66.7,76.7$ and $74.5 \%$ respondents in LAR, MAR and HAR, respectively) supplemented monthly, $14.2 \%(11.7,14.2$ and $16.7 \%$ respondents in LAR, MAR and HAR, respectively), Ad libitum, 7.1\% (12.5, 5 and 3.9\% respondents in LAR, MAR and HAR, respectively), weekly and 6.1\% (9.2, 4.2 and $4.9 \%$ respondents in LAR, MAR and HAR, respectively) seasonally. Benefits of salt supplementation did not differ $(p=0.587)$. The perceived benefits of salt supplementation were improved growth rate, fertility, and milk yield (89.2, 94.2 and $92.2 \%$ respondents in LAR, MAR and HAR, respectively), increased milk yield and body condition (8.3, 4.2 and $4.9 \%$ respondents in LAR, MAR and HAR, respectively), short fattening period $(0.8,1.7$ and $2.9 \%$ respondents in LAR, MAR and HAR, respectively), increased milk yield ( $0.8 \%$ respondent in LAR) and improved fertility $(0.8 \%$ respondent in LAR). Reasons for not supplementing agro-industrial byproducts (AIBP) did not differ $(p=0.691)$. Unavailability $(90,88.3$ and 88.2 respondents in LAR, MAR and HAR, respectively), lack of access $(4.2,5$ and $7.8 \%$ respondents in LAR, MAR and HAR, respectively), and lack of information (5.8, 6.7 and 3.9\% respondents in LAR, MAR and HAR, respectively) were the main reasons for not supplementing AIBP.

\subsection{Perceptions on Body Condition of Animals}

The bodyweight (body condition) of livestock during the dry season was perceived to be significantly poor $(74.2 \%, 100 \%$, and $97.1 \%$ of respondents in LAR, MAR and HAR, respectively), medium (13.3\% of respondents in LAR and $12.5 \%)$ and good $(2.9 \%$ of the respondents in LAR and HAR, respectively). During the wet season, the body condition of animals was indicated to be good $(73.3 \%, 67.5 \%$ and $67.6 \%$ of respondents in LAR, MAR and HAR, respectively), medium $(16.7 \%, 10 \%$ and $11.8 \%$ of respondents in LAR, MAR and HAR, respectively), and poor $(10 \%, 22.5 \%$ and $20.6 \%$ of respondents in LAR, MAR and HAR, respectively). The good body condition of animas was associated with sufficient availability and quality of feeds during the dry season, while the poor body condition shows the impact of the sever seasonal variation in feed availability and quality and diseases $(74.2 \%, 100 \%$ and $94.1 \%$ of respondents in LAR, MAR and HAR, respectively) on the development of body weight. Feed shortage and diseases $(10 \%, 22.5 \%$ and $20.59 \%$ of respondents in LAR, MAR and HAR, respectively) was perceived as causes of poor body condition of animals in the wet season.

\subsection{Perceptions on Land Degradation, Its Causes and Impacts on Livestock Performance}

Grazing land was seen to be degrading. Causes varied, but focused on vegetation and soil erosion (Table 10). Degradation was seen to have negative impacts on animal performance and production. Climate change, overgrazing, expansion of aridity, resettlement and erosion-induced soil fertility decline were major influences on grass species composition changes. Perceived indicators of degradation included bare ground, gullying, changes in grass species, poor grass cover or biomass production, and poor cattle performance.

Table 10. Farmers' perceptions on land degradation, its causes and impacts on animal performance in cross-sectional survey of 342 smallholder farmers around the Gilgel Gibe catchment, southwest Ethiopia.

\begin{tabular}{|c|c|c|c|c|c|}
\hline \multirow{2}{*}{ Parameter } & \multicolumn{4}{|c|}{ TARs } & \multirow{2}{*}{$p$-Value } \\
\hline & LAR & MAR & HAR & Mean & \\
\hline \multicolumn{6}{|l|}{ Do you perceive grazing land degradation over time (\%) } \\
\hline Yes & 100 & 100 & 100 & 100 & \\
\hline No & 0 & 0 & 0 & 0 & \\
\hline Perceived causes of land degradation (\%) & & & & & 0.000 \\
\hline Soil erosion & 11.7 & 91.7 & 92.2 & 65.2 & \\
\hline Overgrazing & 64.2 & 0.8 & 0 & 21.7 & \\
\hline Deforestation and expansion of crop land & 7.5 & 3.3 & 3.9 & 4.9 & \\
\hline Intensive grazing & 16.7 & 4.2 & 3.9 & 8.2 & \\
\hline $\begin{array}{c}\text { Negative impact of land degradation on animal } \\
\text { performance }(\%)\end{array}$ & & & & & 0.000 \\
\hline Poor body condition & 5 & 78.3 & 81.4 & 54.9 & \\
\hline
\end{tabular}


Table 10. Cont.

\begin{tabular}{|c|c|c|c|c|c|}
\hline \multirow{2}{*}{ Parameter } & \multicolumn{4}{|c|}{ TARs } & \multirow{2}{*}{$p$-Value } \\
\hline & LAR & MAR & HAR & Mean & \\
\hline Poor productivity & 78.3 & 7.5 & 7.8 & 31.2 & \\
\hline Increased mortalities & 7.5 & 7.5 & 4.9 & 6.6 & \\
\hline Poor fertility/repeat breeding & 9.2 & 6.7 & 5.9 & 7.3 & \\
\hline Causes of change in grass species composition (\%) & & & & & 0.000 \\
\hline Climate change & 0.8 & 100 & 100 & 66.9 & \\
\hline Overgrazing & 60 & 0 & 0 & 20.0 & \\
\hline Expansion of cropland & 25.8 & 0 & 0 & 8.6 & \\
\hline Expansion of aridity \& resettlement & 11.7 & 0 & 0 & 3.9 & \\
\hline Poor soil fertility & 1.7 & 0 & 0 & 0.6 & \\
\hline Trends of change in grass species over time (\%) & & & & & 0.235 \\
\hline Exist & 94.7 & 98.3 & 95.1 & 96 & \\
\hline Do not exist & 5.8 & 1.7 & 4.9 & 4 & \\
\hline
\end{tabular}

\subsection{Utilization of Communal Grazing Lands}

Majority (93.5\%) of the respondents indicated that there was no control access to communal grazing land, while $9.5 \%$ said that access was possible only through permission from the nearby community. Low biomass production $(86.8 \%)$, increase in unpalatable plants $(6.7 \%)$ and distance $(6.6 \%)$ were the main problems farmers perceived in utilization of communal lands. Low biomass production was caused mainly by uncontrolled overgrazing $(81.2 \%)$ and long dry season/poor rain $(19.8 \%)$. There was no community rule that enforces the balance between animal numbers and pasture feed resources, resulting in over-exploitation and deterioration of common land due to overgrazing. Sometimes access to communal grazing land is restricted by the members of the community belong to a particular grazing land.

\subsection{Indigenous Grazing Land Management Practices}

Knowledge of indigenous management of grazing land and technical methods to mitigate degradation was very poor, not to say non-existent in the study area. Almost all $(99.3 \%)$ respondents did not practice grazing land management. The two indigenous methods used for the management of grazing resources were burning and clearing of unpalatable species $(0.2 \%$ of respondents) and reserved paddocks/standing hay $(0.28 \%)$.

\subsection{Livestock Diseases and Treatment Options}

Major diseases of livestock prevailing in the study area are presented in Table 11. About $80.08 \%, 11.14 \%$, and $8.77 \%$ of respondents reported infectious diseases, respiratory diseases, and parasitic infestations, respectively, as the most important health problems/conditions negatively affecting the economic efficiency of livestock. About $78.63 \%$, $3.54 \%, 5.98 \%$, and $11.85 \%$ of respondents used veterinary medicines, both veterinary and traditional medicines, informal sourced drugs, and traditional medicines, respectively, to treat their sick animals. Diseases $(80 \%)$ and feed shortage $(20 \%)$ were indicated to be the main causes of animal mortality. Few respondents $(8.8 \%)$ indicated bloating as a feedrelated health problem, particularly in the high altitude region due to feeding of herbaceous legumes. The results showed that government is the only provider of veterinary services; however, the farmers had to pay the prices of drugs as the case may arise. Practice of routine vaccination of livestock against infectious diseases was not common in the study area, except during severe disease outbreaks, which was provided by the government during vaccination campaigns free of charge. 
Table 11. Livestock diseases and treatment options in cross-sectional survey of 342 households around the Gilgel Gibe catchment, southwest Ethiopia.

\begin{tabular}{|c|c|c|c|c|c|}
\hline \multirow{2}{*}{ Parameter } & \multicolumn{4}{|c|}{ TARs } & \multirow{2}{*}{$p$-Value } \\
\hline & LAR & MAR & HAR & Mean & \\
\hline Major diseases of livestock & & & & & 0.339 \\
\hline Infectious diseases & 75 & 85.83 & 79.41 & 80.08 & \\
\hline Respiratory diseases & 14.17 & 7.5 & 11.76 & 14.14 & \\
\hline Parasites (external \& internal) & 10.83 & 6.67 & 8.82 & 8.77 & \\
\hline Disease treatment option & & & & & 0.000 \\
\hline Veterinary medicine only & 0 & 0.83 & 9.8 & 3.54 & \\
\hline Drug purchased informally & 7.5 & 7.5 & 2.94 & 5.98 & \\
\hline $\begin{array}{l}\text { Veterinary and herbal medicines } \\
\text { methods }\end{array}$ & 80.83 & 82.50 & 72.55 & 78.63 & \\
\hline Traditional medicines & 11.67 & 9.17 & 14.71 & 11.85 & \\
\hline Reasons for death of animals & & & & & 0.878 \\
\hline Feed shortage & 19.17 & 19.17 & 21.57 & 19.97 & \\
\hline Diseases & 80.83 & 80.83 & 78.43 & 80.03 & \\
\hline Feed related diseases & & & & & 0.599 \\
\hline Available & 10 & 6.67 & 9.80 & 8.82 & \\
\hline Not exist & 90 & 93.33 & 90.2 & 91.18 & \\
\hline
\end{tabular}

\subsection{Housing Management}

The majority of the respondents used either a fence or kraal to keep their cattle overnight, which were unable to protect animals from extreme weather hazards like excessive rain, cold and wind. However, calves and pregnant cows were given special attention in regard to the provision of housings. The majority $(86.7 \%)$ of respondents $(83 \%$, $87.5 \%$ and $89.2 \%$ in LAR, MAR and HAR, respectively) housed pregnant cows in the family dwelling at night time, while $13.3 \%$ (16.7\%, $12.5 \%$ and $10.8 \%$ respondents in LAR, MAR and HAR, respectively) were housed in a separate shed. With regard to calves, $89.9 \%$ of the respondents $(94.2 \%, 83.3 \%$ and $92.2 \%$ respondents in LAR, MAR and HAR, respectively) housed in the family dwelling, whereas $10 \%$ of the respondents $(5.5 \%, 16.7 \%$ and $7.8 \%$ in LAR, MAR and HAR, respectively) provided a separate shed made for calves.

\subsection{Breeding Practices}

Uncontrolled natural mating was the only livestock breeding method practiced in the study area, using any breeding male that is readily available in the area. There were no specific breeding seasons, and parturitions occur throughout the year, resulting in unplanned parturition without considering feed availability. In mixed farming systems, male cattle are primarily kept for draught power, and castrated as soon as they reach draught age. Therefore, the few bulls available are used to mate even close relatives, possibly leading to inbreeding, which results in genetically inferior animals, low performance, and sexually transmitted diseases. It was observed that there was no practice of bull selection for breeding due to lack or low number of bulls available within herds. Practice of estrus detection was uncommon, but farmers stated signs of cows' readiness for mating such as restlessness, proximity of cows to bulls, vaginal discharge and mounting of other animals. None of the respondents reported pregnancy diagnosis after mating. When asked how a pregnancy is confirmed, they mentioned that cows not being stood to be mated, reduced milk yield, prevents suckling by her calf, and increased sizes of vulva, udder and abdomen as the signs of confirming pregnancy. The uncontrolled mating often took place at communal grazing.

Farmers that had low knowledge about effects of inbreeding used their own bulls as long as possible, allowing them to mate with close relatives. They perceived that mating of related animals has no problem on productive and reproductive performance of their progeny. Bulls attained age of puberty at about 4 years and are used for breeding at about 6-9 years of age, after which they were castrated to be fattened for sale. The use of artificial 
insemination (AI) for genetic upgrading was non-existent. Hence, it is recommended that the government should provide AI facilities for genetic improvement of the local breeds for enhancing productivity. The productive and reproductive performance of cattle in the study area was low, characterized by low milk production, short lactation length, delayed age at puberty and first calving, and long calving interval as documented in the first paper of part of this study [31].

The results revealed that none of the respondents keep written records, but used mental record keeping of their livestock events. Animals were identified by traditional identification methods such as coat color, name, and other physical futures of the animal (shape of horn, ear, color spot on forehead and face, etc.).

\subsection{Sources of Water}

The main sources of water for livestock in the study area were the Gilgel Gibe hydroelectric dam, temporary and perennial rivers. Frequency of watering per day was twice $(100 \%)$ during the dry and once $(100 \%)$ in the rainy season. Parasitic leech was reported as the most important water related health problem in the HAR during the dry season when rivers flow is reduced.

\subsection{Major Constraints to Cattle Production}

The study indicated that respondents faced multiple constraints to cattle production. Overall, $72.4 \%$ of the respondents $(41.2 \%, 80.8 \%$ and $98.1 \%$ in LAR, MAR and HAR, respectively) perceived lack of availability and quality feed, especially in the dry season, animal diseases, and low genetic potential of indigenous animals as the most important constraints to livestock production, in descending order. Whereas $27.6 \%$ of the respondents $(58.8 \%, 19.2 \%$ and $4.9 \%$ in LAR, MAR and HAR, respectively) reported animal diseases, feed shortage and poor performance as major challenges to livestock production, in that order. According to both the farmers interviewed and key informants, poor quality and insufficient availability of feed, particularly in the dry season, was considered as the major constraint limiting livestock production and productivity.

\section{Discussion}

This study is the first detailed study that describes livestock feed resources, feeding practices and coping strategies with the impacts of feed scarcity, and major constraints for livestock production in mixed crop-livestock farming systems around the Gilgel Gibe catchment, Ethiopia. The findings of the study will provide valuable insight and baseline data to better understand the livestock feed resources, feeding management and mitigation strategies during feed scarcity. It will also help to guide policy makers and other livestock stakeholders to formulate appropriate feed-related intervention strategies that enhance adequate and quality feed supply to increase livestock productivity and farmers livelihoods.

\subsection{Socio-Economic Characteristics of Respondents}

Of all respondents interviewed, majority were men, and middle-aged suggesting that youths were not engaged in crop-livestock farming in the study area mainly due to limited access to land, and the educated youth migrate to big towns for employment in other sectors. The observed large household size might be attributed to the polygamous marriage practice. Large family size was also considered very important for providing adequate labor for both crop and livestock farming that requires higher labor inputs. The fact that the majority of the respondents were illiterate would likely affect acceptance, adoption, and use of improved feed and livestock production technologies. Hence, providing basic education to them would be essential for easy acceptance and use of improved livestock technologies. Mulugeta [32] reported that low education level of farmers can have an influence on transfer of improved agricultural technologies and their participation in development.

The study revealed that respondents had small land size attributed to high population growth. The interviewees allocated larger proportion of their land for crop production 
than grazing, indicating that higher priority was given to meet household food security first. Belay et al. [33] also reported that farmers allocated larger proportion of their land (63.2\%) for crop production than grazing land in Dandi district. Respondents stated that landholding will continue decreasing consistently due to rapidly increasing population, leading to diminishing grazing lands, reduced livestock productivity, and food insecurity.

\subsection{Farming System}

The study regions were characterized by mixed crop-livestock production systems, where both crops and livestock production were practiced within the same management unit. Barley, maize, sorghum, tef, wheat, fab beans, haricot beans, field peas and lentils were the major food crops grown by respondents in the study area. Coffee and khat are the major cash crops, whereas fruits, root crops and vegetables are grown for both domestic consumption and sale. Crop production was primarily rainfed. Livestock species kept by the respondents included mainly cattle, followed by small ruminants, poultry and equines, and were used for different purposes. The main source of household income was crop production followed by livestock. Both crops and livestock interact through exchange of inputs and outputs. Livestock, particularly cattle, provided draught power and organic manure for crop farming. Behnke and Metaferia [34] also indicated that livestock provide most of the needed draught power for about $80 \%$ of mixed farmers who use animal traction to plough their crop fields. Moreover, livestock provide cash income or purchasing inputs required for crop production, while crops provide crop residues to feed livestock, especially during the long dry season when the availability of natural pasture is scarce. Surplus crops are also sold when available to purchase animals. According to Paris [35], mixed crop-livestock farming systems maximize returns from limited land and capital, diversify sources of income, minimize production risk, provide food security, and increase productivity.

\subsection{Cattle Herd Size and Reasons for Keeping}

Cattle were the predominant livestock species kept in the study area. However, the small cattle herd size per household was attributed to shortage of feed and grazing land, which was in turn attributed to rapid population growth and expansion of crop land at the expense of grazing lands, leading to small herd size. Therefore, given the limited and diminishing grazing land resources, the small cattle numbers owned by respondents seems rational. The mean cattle herd size reported in this study is lower than the findings of Andualem et al. [36], but higher than that of Belay et al. [33] in mixed farming systems elsewhere in Ethiopia.

The entire cattle breed kept by the respondents were the indigenous zebu (Bos indicus), which could be due to their well adaption to the local tropical production environment, despite their low milk production potential, lack of access to artificial insemination services (AI) for crossbreeding with exotic dairy genotypes, and lack of supply and high cost of improved breeds. The study found that breeding females constituted a higher proportion of the herds kept by respondents, which show that sustainability of the cattle herd relies on considerable proportion of breeding females in the herd for producing replacement heifers for milk production, male animals for draught power and income generation. The finding of the present study supports that of CSA [37], which reported that the female and male cattle comprised about $56 \%$ and $44 \%$, respectively, of all cattle population owned by smallholder farmers in Ethiopia.

\subsection{Trends in Livestock Population and Composition}

More than half of the farmers reported that the total livestock population has been increasing over the last 20 years, mainly due to human population growth and increasing demand for sources of draught power, milk, meat, and cash income. In the study regions, land preparation for crop production was entirely relied on draught oxen, and livestock is the second most important source of household income. Cattle are the only source of milk 
for household consumption, and sale of traditional dairy products generates income to the household. On the other hand, farmers indicated that livestock herd size per household has shown a decreasing trend, and currently they kept small herd sizes compared to 20 years ago, mainly due to shortage of feed and grazing land. Regarding change in livestock composition per household, a decrease in number occurred in cattle compared to small ruminants, and was closely associated with shrinkage in grazing land and feed scarcity.

\subsection{Feed Resources and Feeding Practices}

Natural pasture was reported to be the most important source of feed, especially in the rainy season followed by crop residues. FAO [38] also indicated that crop residues and natural pasture are the main source of feed in Ethiopia accounting for $95 \%$ of the feed biomass. However, the availability and quality of natural pasture was generally good in the rainy season (June to September), and meets the nutrient requirements of animals, and subsequently improves livestock productivity. However, it shows rapid decline in availability and quality as the dry season advanced (October to February), limiting livestock productivity. The area also receives short rains between March and May allowing some regrowth of natural pasture forages improving feed availability to a limited extent. Average land size allotted for natural pasture was very small ( $0.17 \mathrm{ha})$, which is caused by decline in fallow land or continuous cultivation and expansion of cropped land at the expense of grazing lands to meet the increasing household food demand, leading to a shortage of natural pasture. The finding that natural pasture was the major feed resource in the current study converges with report of previous studies $[33,36]$ under mixed crop-livestock farming systems.

Besides fluctuation in quantity, natural pasture is also low in nutritive value (energy, $\mathrm{CP}$ and minerals) in the dry season. As a result, the supply of nutrients could support only maintenance requirement, and this limits optimal livestock productivity. This was substantiated by the fact that $96 \%$ of respondents stated their animals lost weight in the dry season due to limited availability and poor quality of natural pasture. Gemiyo et al. [39] reported that the $\mathrm{CP}, \mathrm{NDF}, \mathrm{ADF}$, and IVDMD content of natural pasture were $8.38 \%, 60.86 \%$, $40.71 \%$, and $57.20 \%$, respectively, indicating significantly lower CP content compared to that needed for adequate rumen microbial activity, whereas the NDF, ADF and IVDMD were higher limiting nutrient availability to animals. Hence, there is a need to introduce improved herbaceous and multi-purpose tree and shrub legumes which suits the local environment, conserve feeds, urea treatment of crop residues when affordable to improve $\mathrm{CP}$ content and digestibility, training farmers on efficient utilization of locally available feed resources, and strategic supplementation with good sources of energy and protein feeds in order to improve availability and quality of natural pasture.

Crop resides were reported to be the second most important feed resources, especially during the dry season to bridge limited availability of natural pasture. However, their production is seasonal, that is they are available in large quantities right after crops have been harvested and they are not available during other periods. Moreover, they are used or other purposes such as fuel and construction material (maize and sorghum stovers), roof cover, and source of income (tef straw). Regardless of the altitude regions, the major sources of crop residues were barely, tef (Eragrostis tef (Zucc) T.), wheat (Triticum aestivum), maize (Zea mays L.), and sorghum (Sorghum bicolor L.). Other sources of crop residues used in a limited extent were chickpea (Cicer arietinum L.), haricot bean (Phaseulus vulgaris L.), faba bean (Vicia faba L.), field peas (Pisum sativum L.), and lentil (Lens culinaris). Despite their significant importance as source of feed in the dry season, crop residues are bulky, seasonal in availability, and have high lignin values, low contents of crude protein, vitamins and minerals, low digestibility, slow fermentation in the rumen and poor in palatability [40]. Previous studies reported that crop residues commonly have low metabolizable energy (ME) values of 5-7 MJ ME/ kg DM and CP values of 2-5\% [41]. Gemiyo et al. [39] reported that the CP, NDF, ADF, and IVDMD contents of crop residues were $5.77 \%, 75.97 \%, 45.16 \%$, and $46.05 \%$ in mixed farming systems in southern Ethiopia, showing significantly lower 
$\mathrm{CP}$ content than the critical level of 7\%. Thus, there is a need for adoption of intercropping dual purpose (feed and food) legume forages with cereals to improve the quality and quantity of crop residues, provide high quality protein for family consumption and to enhance soil fertility. Moreover, introduction of multi-purpose fodder trees and shrubs on traces, farm boundaries, soil and water conservation structures, and around homesteads as strategic resources to provide green leaves as a source of protein to supplement the poor quality crop residues during the dry season. Mechanical chopping, and urea treatment crop residues for improving its nutritional value when affordable, supplementation with good sources of energy and protein feeds could be of paramount importance for improving the nutritional quality, intake and digestibility of crop residues.

During our field observations, we witnessed that most of the crop residues produced in the study area were left where the crop is threshed or in the field and fed in situ. The main constraints for the inefficient utilization of crop residues as reported by the respondents were limited labor, lack of storage facilities, transportation, and far from where the animals are kept, resulting in reduced quality and wastage of crop residues due to soiling and trampling by animals. Therefore, considerable amount of labor is needed in transporting even over short distances and storing because of their bulky nature. Moreover, crop residues lose leaves before harvesting, during transporting and storage, resulting in biomass and nutrient losses. Therefore, there is a need to educate and encourage farmers to effectively collect, store, process, and properly utilize crop residues. Moreover, introduction of appropriate, cost-effective and simple technologies such as chopper and bailing woodenbox, and use of equines for crop residue transportation are essential to reduce labor requirement and improve crop residues utilization or feed availability in the dry season when there are limited natural pasture availability. A previous study [42] showed that owing to their bulky nature, proper handling of crop residues during harvesting and transportation, use of appropriate storage facilities that minimizes losses through bleaching and consumption by pests and rodents may improve their utilization.

\subsection{Feeding Practices}

Free grazing was the predominant feeding system practiced in the study area. However, free movement of animals was controlled or restricted by herding in the rainy season to prevent the animals from damaging crops. Right after crops were harvested, livestock were left to freely graze aftermath/stubbles, fallow lands, natural pasture, and roadsides grasses and forest areas. The free grazing system is characterized by seasonal fluctuations in feed resources availability, thereby limiting the intake of essential nutrients (energy, minerals and protein), especially during the dry season. Hence, strategic supplementation with good sources of energy and protein feeds based on physiological and production status of animals would be of valuable importance to improve productivity. The finding of this study concurs with results of previous studies [20,21,36], who also reported that livestock feeding management was based predominant on free grazing system in most part of the extensive and smallholder crop-livestock farming systems in Ethiopia.

\subsection{Improved Forage Cultivation}

The results of the current study showed that there was no practice of improved forage cultivation in the study area. Insufficient land and lack of technical information on how to establish, manage, and utilize improved forages was reported to be the main reasons for non-adoption of the technology. Kabirizi et al. [43] also reported that lack of knowledge on forage production and utilization was a common constraint in developing countries to adopt the technology. Assefa et al. [44] reported that land shortage, lack of awareness and high price of forage seed were the main constraint that hinder the adoption of improved forage crop production. In Ethiopia, planted forages make up only less than $1 \%$ of cultivated land [45], implying a lot of effort is need to introduce the technology to improve feed supply. Thus, in view of the land shortage, we suggest growing leguminous forages in association with food crops, on soil and water conservation structures, around 
homestead, introduction of multi-purpose trees and shrubs which are capable of providing both forage and other products, and establishing forage demonstration sites at the existing farmers training centers and adequate extension services would be important entry points to raise farmers' awareness and technical knowledge towards adoption of improved forage technologies. With the current critical challenges of feed shortage, introduction of improved forage production broadly into livestock development packages should be given high priority. Technical information about multiple roles of improved forages as source of feed for livestock, food for humans, improving soil fertility through biological nitrogen fixation, control of erosion, and for construction and fire wood needs to reach farmers extensively to better understand importance of forage crops. Wambugu et al. [41] reported that policy, research and extension efforts aimed at demonstrating the benefits of feed-based technologies are central in encouraging farmers to adopt improved forage technologies.

\subsection{Feed Shortages and Coping Strategies}

The results revealed that all the farmers interviewed experienced a critical feed scarcity during the dry season, resulting in decreased livestock productivity and mortality. Moran [46] also reported acute shortage of feed supply and very poor quality during the dry season. Lukuyu et al. [47] reported that seasonal fluctuations in feeds supply results in slow growth rate, loss of body condition, low production and reproductive performance, and increased susceptibility to diseases and parasites. Increased use of bulule (grain mill leftovers), using crop residues and non-conventional feeds, conserving hay, purchasing green feeds and reducing herd size were used as coping strategies to feed scarcity by dairy farmers [33]. Changing of feed resources based on availability and cost, purchasing of feed ingredients in bulk, using crop/food wastes, harvesting of forages growing naturally in open access lands and reducing herd size were strategies used for coping with feed scarcity among urban and peri-urban livestock farmers in Kampala, Uganda [48]. The fact that respondents in the current study destocked their animals as coping strategy to feed scarcity concurs with that of Dhakal et al. [49] who observed that farmers in Nepal reduced their livestock during feed scarcity. The results of the study suggest the need for improving the utilization of locally available conventional and non-conventional feed resources, grazing land management, adoption of rotational grazing, feed conservation (hay and crop residues), supplementation of poor quality crop residues and dry natural pastures, improving crop residues quality, forage cultivation where land is not a limit or integration with cereal crops for providing feed for animal, and food and fuel wood for humans without reducing land for crop production seems to be essential intervention for coping with dry season feed scarcity.

\subsection{Perceptions on Land Degradation}

The respondents had clear perceptions of natural pasture or grazing land degradation. This shows that they were able to identify land alteration and attributed it to some factors as causes. The farmers' perceived causes of land degradation will influence the interventions towards its future management. An increase in human and livestock population, and diminishing grazing land have put increasing pressure on natural pastures, leading to overgrazing, resulting in land deterioration. Similar to our findings, overgrazing has been identified as the major anthropogenic cause of grazing land degradation, while poor rainfall is the main natural cause of degradation [50]. According to the interviewed farmers, the shrinkage of grazing lands has led to overgrazing, resulting in declined quality and quantity of pasture forages, decrease in palatable species and increase in unpalatable species, sever erosion, soil compaction and subsequent land degradation. Moreover, population growth has led to sever deforestation for crop land expansion, construction materials, fire wood, fencing, household furniture, and charcoal production for income generation, resulting in climate change and subsequent land degradation. Tekalign [51] reported that environmental degradation due to deforestation and overgrazing have significantly reduced soil fertility and grazing land productivity. Oldeman et al. [52] estimated that over- 
grazing causes $35 \%$ of land degradation, whereas agricultural activities and deforestation are responsible for $28 \%$ and $35 \%$, respectively.

The practice of uncontrolled free grazing throughout the year in the study area has led to deterioration of the grazing land due to overgrazing, which has resulted in decreased vegetation cover, declining pasture productivity, soil erosion and grazing land degradation. Previous studies $[53,54]$ also indicated that grazing lands in the mixed farming system of Ethiopia were seriously overloaded with stocks generally beyond their optimum carrying capacity, leading to overgrazing, erosion, and overall land degradation. From results of this study, overgrazing has exerted pressure on grazing land, thus leading to degradation. Hence, unless effective measures, which regulate livestock and human population, are put in place, the diminishing of grazing lands will worsen the existing problems of overgrazing, erosion and land degradation. It has been recommended that in degraded grazing land, the reduction of stock number and controlled grazing lower grazing pressure in order to facilitate rehabilitation [55]. Therefore, in order to restore, sustain and enhance the productivity of degraded grazing lands in the present study, controlled grazing, proper grazing land management, rotational grazing systems to give sufficient time for pasture forages to recover between grazing intervals, balancing number of animals with capacity of pasture resources, adoption of intensive production when affordable, and development of community level common land utilization bylaws are recommended to reduce the negative impact of overgrazing on land degradation and their long term sustainability.

Climate change, both a rise in temperature and a reduction in rainfall, was perceived by respondents as the main causes of change in grass species composition of grazing lands. Respondents stated that palatable grass species of pastures have decreased, while nonedible or unpalatable species not often seen before and bushes showed increasing trend from time to time due to climate change. Based on the information obtained from livestock and feed development experts in the study area, climate change has led to alterations in natural pasture grass species, reduced biomass/yield, decreased ground cover and edible species, and increased weeds/non-edible species, reduced grass height, and increased bare grounds. Generally, grazing land grass species composition in the study area has suffered from climate change, expansion of cultivation into grazing areas, fall in rainfall, resettlement, erosion induced decline in soil fertility, and overgrazing as perceived by the farmers. This emphasizes the importance of appropriate interventions like over sowing of grazing lands with perennial grasses and legume species to maintain higher proportion of palatable pasture species.

\subsection{Utilization of Common Grazing Lands}

From the results of the study, there was no restriction on access to common grazing lands. There was no control of livestock numbers and days grazing on common land due to lack of regulation guidelines. This has led to overexploitation of grazing resources, resulting in overgrazing and subsequent land degradation. This calls for training and raising awareness of the community on proper management of common grazing lands for sustainable utilization.

There was no practice of grazing land management adopted by respondents to improve its productivity. As a result it is subjected to heavy overgrazing due to uncontrolled and continuous grazing by ever increasing livestock population. Farmers indicated that they had a very poor access to extension services and technical know-how on improved management of grazing lands. Thus, it would be imperative to educate farmers to adopt different grazing land management strategies such as stock exclusion from severely degraded grazing lands, rotational grazing, clearing of invasive and unpalatable species, avoiding overgrazing or balancing the number of animals with available natural pasture forage resources, and over sowing with improved perennial grasses and legumes species to improve sustainable availability and quality of grazing land. This requires strong support of government extension services and community participation for sustainability of communal grazing resources. 


\subsection{Livestock Diseases}

Diseases and parasites were reported to be the major health challenges of livestock and negatively affected the economic importance of their animals through morbidity, reduced performance, poor body condition and mortality. It was observed that the prevalence of livestock diseases and parasites decreased from low to high altitude regions of the study sites. In the low altitude region, trypanosomiasis, tick infestations and tick-borne diseases were frequently reported as economically important diseases diversely affecting animal health and productivity, but were of low importance in the high altitude region. In the low altitude region, farmers reported facha (tsetse fly) as the major causative agent in the spread of trypanosomiasis. Internal parasites were reported to be major health problems mainly during the rainy season when animals grazed on marshy and wet land pastures.

According to the information obtained from the experts of livestock health offices of respective districts, anthrax, black leg, contagious bovine pleuropneumonia, foot and mouth disease, gastro intestinal parasitism, hemorrhage septicemia, reproductive health disorders, lumpy skin diseases, mastitis, newcastle disease, rabies, pasteurellosis, respiratory diseases, trypanosomiasis, tick and tick-borne diseases are the major health problems of livestock prevalent in the study area.

The practice of self-treating of sick animals by some respondents in the study area using drugs (antibiotics) sourced through both formal and informal outlets without veterinarian prescription may lead to animal losses and inappropriate use of antibiotics. This could also result in drug resistant strains in livestock, and can lead to significant public health risks through consumption of animal products from such animals. This requires priority attention by concerned bodies to stop the practice and effective veterinary services. Few respondents reported using traditional (herbal) medicines to treat their sick animals due to unavailability of veterinary services, distant location of veterinary clinics, high cost of medicines, and the herbal medicines are cheaply and easily available in their area. It was not possible to obtain information on types and details of the herbal medicines used to treat diseases because the cattle farmers themselves do not know, because it is prepared by traditional ethno-veterinary herbalists who are not willing to disclose the information, as it is part of their source of income. According to the respondents, the government is the only provider of veterinary services, but farmers also purchased drugs from informal sources and local veterinary pharmacies.

No respondent reported isolation of sick animals from their healthy herds due to lack of awareness and separate sheds. Practice of routine vaccination was non-existent among the respondents, except during the government mass vaccination campaign of infectious disease outbreaks. Poor animal health extension services, inaccessibility of veterinary services, lack of awareness, and limited capital could be the main causes for the lack of regular vaccination practices.

From the results of the study, it would be important to make all possible efforts to prevent or control diseases through appropriate animal health management practices such as regular vaccination, deworming, spraying, good hygiene in animal housing, and access to adequate veterinary services. The study observed that veterinary facilities were not available close to the farmers. Thus, training para veterinarians among the community and enhancing the supply of drugs and vaccines would help to reduce animal health challenges. Future in-depth epidemiological and laboratory-based diagnostic studies of the reported diseases would be imperative to develop and implement effective disease preventive, control and treatment measures.

\subsection{Farmers' Perceived Constraints to Livestock Production}

Feed shortage, high prevalence of diseases, and poor genetic potential of the local livestock breeds were reported to be the major challenges to livestock production. Feed scarcity was indicated as the most serious constraint limiting livestock productivity, especially during the dry season. Feed supply relied mainly on natural pasture grazing, roadside grasses, and crop residues. The available natural pasture was able to sustain 
better livestock productivity only during the rainy season. However, both available and quality of natural pasture and crop-residues are low in the dry-season limiting nutrient availability to animals, and resulting in reduced performance. Commercial concentrates and agro-industrial byproducts are unavailable in the study area. Improved forage cultivation was non-existent limiting feed availability attributed to land scarcity and lack of information on forage production and management. Hence, in order to improve feed supply in both quantity and quality, especially in the dry season, there is a need to efficiently utilize locally available feed resources, value addition of crop residues when the cost of urea is affordable, improved forage cultivation whenever land is available or growing forage in association with food crops as a strategy to maximize the use of land, strategic supplementation, introduction of fodder trees and shrubs production on terraces, farm boundaries, and around backyard for dry season supplementation. Our findings show that lack of land was the main reason for non-adoption of forage production concurs with that of Kabirizi et al. [43], which reported that shortage of land was the most important cause of feed scarcity. The same authors also reported that integration of pastures into existing cropping systems might partly reduce the land scarcity challenges [42]. The findings of the present study supports that of [56], who also reported that feed shortage is the most critical constraint to livestock production in the tropics in general.

High prevalence of diseases and parasites was reported as the second most important constraint to livestock production, leading to significant economic losses to farmers. This could be attributed to lack of or poor access to veterinary services and high cost of drugs and vaccines. Additionally, veterinary services delivery is limited to government and no private service providers to reach the farmers whenever animals get sick. This calls for access to strategically located veterinary services to maintain livestock health.

Poor genetic potential of the local breeds was also mentioned as important challenge to livestock production, and was attributed to lack of access to artificial insemination (AI) to crossbreed with exotic genes to improve genetic merit of local breeds to enhance livestock productivity, especially that of cattle. Therefore, provision of AI to improve the genetic potential and productivity of local animals would be a valuable strategy to alleviate this problem. However, it is advisable to improve the availability and quality of feeds, animal health services, and to identify the appropriate exotic gene before crossbreeding the local cattle. The findings of our study regarding constraint to livestock production are in agreement with reports of previous studies $[33,36,57]$ in mixed farming systems elsewhere in Ethiopia.

\section{Conclusions}

This study assessed feed resources, feeding practices, coping strategies to feed scarcity, and major challenges to livestock production in smallholdings. Mixed crop-livestock production was the dominant farming system in the study regions practiced for reducing livelihood risks, optimizing the use of limited resources (land), and diversifying income sources for more security in maintaining household livelihoods. Livestock is an integral part of the mixed farming systems in the region and provided multiple products and services. Natural pastures, crop residues, roadsides grasses and non-conventional feeds were the most important livestock feed resources. The results of the study revealed that farmers made efforts to overcome the impacts of feed scarcity on livestock production using various coping strategies such as conserving crop residues and hay, purchasing roughages, reducing herd size and renting grazing land. The main constraint for the efficient utilization of crop residues was lack of labor, storage facilities, and transportation, resulting in loss of residue dry matter and quality. The main barriers for the non-adoption of improved forage production were insufficient land and lack of knowledge about production, management and utilization of improved forages. Livestock feeding practice in the study area was mainly dominated by free-grazing system. Whatever available supplementary feeds were predominantly provided to target classes of animals such as draught oxen, lactating cows, and fattening animals due to their economic importance for draught power, milk produc- 
tion, and income generation. As the survey results showed scarcity of feed, especially in the dry season was the most important challenge limiting improved livestock production and was attributed to shortage of land, crop land expansion, and shrinking communal grazing land. Other constraints facing farmers were high prevalence of diseases and parasites and low genetic merit of the local livestock breeds.

The study showed that grazing land was degrading, and causes varied, but focused on vegetation and soil erosion. According to the farmers, land degradation was seen to have negative impacts on animal performance and production. The study also revealed that climate change, overgrazing, expansion of aridity, resettlement and erosion-induced soil fertility decline were stated to be major influences on grass species composition changes. Farmers' perceived indicators of land degradation included bare ground, gullying, changes in grass species, poor grass cover or biomass production, and poor cattle performance.

Based on our findings, improvement of sustainable feed supply can be achieved through efficient use of locally available feed resources, feed conservation, adopting improved forage production, value addition of low quality crop residues; efficient collection, storage and processing of crop residues, proper grazing land management, grazing management, supplementary feeding when affordable, improved feeding strategies, and adequate extension services on adoption of improved forage technologies and building the capacity of farmers. Moreover, access to efficient veterinary and artificial insemination services would be imperative to prevent or control the prevailing diseases and improve the genetic merits of local breeds.

Addressing the institutional, socio-economic and technical challenges to enhance sustainable livestock production and food security in the study area, will require concerted efforts involving multiple stakeholders such as policy makers, government, extension services, research, livestock development partners, and private sectors, with participation of farmers.

This study contributes to the knowledge and literature gaps in terms feed resources availability and strategies for coping with feed scarcity for ensuring sustainable livestock production and food security. Moreover, it provides information that would be essential for the development and implementation of appropriate policies that will contribute to environmentally and socio-economically sustainable livestock production. Findings of this study would also be of paramount importance for development agencies, government, non-governmental organizations, and policy-makers in formulating and implementing sustainable livestock feed development interventions, feeding strategies, coping with feed scarcity situations and assessing impacts of overgrazing on grazing land degradation to enhance sustainability of livestock production, household food security and the environment.

We recommend that future research should consider evaluation of the nutritive value and quantity of the available feed resources, which would be important to know the supplies and requirement to enable the establishment of feed balance to manage a deficit of feed resources in relation to the livestock population in the study area.

\section{The Limitations of the Study}

Data collection for this study was conducted in cross-sectional studies, thus data were collected at a single point in time. Although we tried to obtain some seasonal information based on farmers' recall, we did not actually monitor the seasonal variation of variables. Overall, due to lack of data recording by farmers, all data collected was based on farmers' memory recall, which might affect precise data availability. Therefore, caution should be applied in interpreting the results, because it was possible that farmers could have either under- or over-reported, which are, of course, common limitations for a survey of this type. The other limitations are the small sample size and specific study area.

Author Contributions: Conceptualization, B.D. and G.P.J.J.; methodology, B.D. and G.P.J.J.; software, B.D.; validation, B.D. and G.P.J.J.; investigation, B.D. and G.P.J.J.; data curation, B.D.; manuscript preparation, B.D.; supervision, B.D. and G.P.J.J. Both authors have read and agreed to the published version of the manuscript. 
Funding: This study was funded by the Institutional University Cooperation Project (IUC) and Jimma University of the Flemish Interuniversity Council (VLIR-UOS) for the PhD study of the first author.

Institutional Review Board Statement: Not applicable.

Informed Consent Statement: Not applicable.

Data Availability Statement: The datasets generated during the current study are available from the corresponding author on reasonable request.

Acknowledgments: The authors would like to acknowledge the financial support of the Institutional University Cooperation Project (IUC) and Jimma University of the Flemish Interuniversity Council (VLIR-UOS) for the PhD study of the first author. We are very grateful to sample farmers for the cooperation and information provided. We are sincerely thankful to the local staffs of the respective Districts Agricultural and Rural Development Offices and development agents for the support during the field survey.

Conflicts of Interest: The authors declare no conflict of interest.

\section{References}

1. Davis, B.; Stefania, D.G.; Alberto, Z. Are African households (not) leaving agriculture? Patterns of households' income sources in rural Sub-Saharan Africa. Food Policy 2017, 67, 153-174. [CrossRef]

2. Herrero, M.; Grace, D.; Njuki, J.; Johnson, N.; Enahoro, D.; Silvestri, S.; Rufino, M.C. The roles of livestock in developing countries. Animal 2013, 7, 3-18. [CrossRef]

3. Herrero, M.; Thornton, P.K.; Notenbaert, A.M.; Wood, S.; Msangi, S.; Freeman, H.A.; Bossio, D.; Dixon, J.; Peters, M.; van de Steeg, J.; et al. Smart investments in sustainable food production: Revisiting mixed crop-livestock systems. Science 2010, 327, 822-825. [CrossRef]

4. Ministry of Agriculture (MOA). Transforming Ethiopian Agriculture. Presented at the Agricultural Scholar Consultative Forum, Addis Ababa, Ethiopia, April 2019.

5. Shapiro, B.I.; Gebru, G.; Desta, S.; Negassa, A.; Nigussie, K.; Aboset, G.; Mechale, H. Ethiopia Livestock Sector Analysis; Project Report; ILRI (International Livestock Research Institute): Nairobi, Kenya, 2017.

6. Azage, T.; Berhanu, G.; Hoekstra, D.; Berhanu, B.; Yoseph, M. Smallholder Dairy Production and Marketing Systems in Ethiopia: IPMS Experiences and Opportunities for Market-Oriented Development; Project Working Paper 31; IPMS (Improving Productivity and Market Success) of Ethiopian Farmers: Nairobi, Kenya, 2013.

7. Central Statistical Agency (CSA). Federal Democratic Republic of Ethiopia.Agricultural Sample Survey 2019/20 [2012 E.C.]: Volume II. Report on Livestock and Livestock Characteristics (Private Peasant Holdings) Ethiopia; Statistical Bulletin 587; Central Statistical Agency: Addis Ababa, Ethiopia, 2020.

8. Azage, T.; Berhanu, G.; Dirk, H. Input Supply System and Services for Market-oriented Livestock production in Ethiopia. In Proceedings of the 14th Annual Conference of the Ethiopian Society of Animal production (ESAP), Addis Ababa, Ethiopia, 5-7 September 2006.

9. Gebregziabher, S.; Mouazen, A.M.; Van Brussel, H.; Ramin, H.; Nyssen, J.; Verplancke, H.; Behailu, M.; Deckers, J.; De Baerdemaeker, J. A review: Animal drawn tillage; the Ethiopian ard plough; maresha. Soil Tillage 2006, 89, 129-143. [CrossRef]

10. Dawit, A.; Ajebu, N.; Sandip, B. Assessment of feed resource availability and livestock production constraints in selected Kebeles of Adami Tullu Jiddo Kombolcha District; Ethiopia. Afr. J. Agric. Res. 2013, 8, 4067-4073.

11. Selamawit, D.; Yeshambel, M.; Bimrew, A. Assessment of livestock production system and feed balance in watersheds of North Achefer District, Ethiopia. J. Agric. Environ. Int. Dev. 2017, 111, 159-174.

12. Welay, G.M.; Tedla, D.G.; Teklu, G.G.; Weldearegay, S.K.; Shibeshi, M.B.; Kidane, H.H.; Gebrezgiabher, B.B.; Abraha, T.H. A preliminary survey of major diseases of ruminants and management practices in Western Tigray province; northern Ethiopia. BMC Vet. Res. 2018, 14, 293. [CrossRef] [PubMed]

13. Adugna, T.; Alemu, Y.; Dawit, A. Livestock Feed Resources in Ethiopia: Challenges; Opportunities and the Need for Transformation; Ethiopian Animal Feed Industry Association: Addis Ababa, Ethiopia, 2012.

14. Alemayehu, M. Feed Resources Base of Ethiopia: Status; Limitations and Opportunities for Integrated Development. Presented at the 12th Annual Conference of the Ethiopian Society of Animal Production (ESAP), Addis Ababa, Ethiopia, 12-14 August 2004.

15. Sanford, J.; Ashly, S. IGAD Livestock Policy Initiative: Livestock Livelihoods and Institutions in the IGAD Region; IGAD LPI Working Paper No. 10-08 the IDL Group; IGAD: Djibouti City, Djibouti, 2008.

16. Makkar, H. Animal Nutrition: Beyond Boundaries of Feed and Feeding; Food and Agriculture Organization: Rome, Italy, 2016.

17. Vighi, G.; Marcucci, F.; Sensi, L.; Di Cara, G.; Frati, F. Allergy and the gastrointestinal system. Clin. Exp. Immunol. 2008, 153, 3-6. [CrossRef] 
18. Absalón-Medina, V.A.; Nicholson, C.F.; Blake, R.W.; Fox, D.G.; Juárez-Lagunes, F.I.; Canudas-Lara, E.G.; Rueda-Maldonado, B.L. Economic analysis of alternative nutritional management of dual-purpose cow herds in central coastal Veracruz; Mexico. Trop. Anim. Heath Prod. 2012, 44, 1143-1150. [CrossRef]

19. Bedasa, E. Study of Smallholder Farms Livestock Feed Sourcing and Feeding Strategies and Their Implication on Livestock Water Productivity in Mixed Crop-Livestock Ssystems in the Highlands of the Blue Nile Basin, Ethiopia. Master's Thesis, Haramaya University, Dire Dawa, Ethiopia, 2012.

20. Getachew, M.; Tsehay, R.; Zelalem, L.; Gerba, L.; Duncan, A.J.; Yeshambel, M. Assessment of Livestock Production Systems; the Potential of Feed Availability; Farming System and Livestock Production Problems in Fogera District, Amhara Region, Ethiopia; Conference Paper; ILRI: Addis Ababa, Ethiopia, 2015.

21. Zemene, W.; Samuel, T.; Taye, T.; Worku, J. Assessment of the Prevailing Cattle Fattening Practices in Jimma Zone, South-Western Ethiopia. Glob. Vet. 2016, 17, 105-113.

22. Nyssen, J.; Poesen, J.; Moeyersons, J.; Deckers, J.; Mitiku, H.; Lang, A. Human impact on the environment in the Ethiopian and Eritrean Highlands-A state of the art review. Earth Sci. Rev. 2004, 64, 273-320. [CrossRef]

23. Hurni, H.; Tato, K.; Zeleke, G. The implications of changes in population; land use; and land management for surface runoff in the Upper Nile Basin area of Ethiopia. Mt. Res. Dev. 2005, 25, 147-154. [CrossRef]

24. Nyssen, J.; Simegn, G.; Taha, N. An upland farming system under transformation: Proximate causes of land use change in Bela-Welleh catchment (Wag; Northern Ethiopian Highlands). Soil Tillage Res. 2009, 103, 231-238. [CrossRef]

25. Gebremedhin, B.; Pender, J.; Tesfay, G. Collective action for grazing land management in crop-livestock mixed systems the Highlands of Northern Ethiopia. Agric. Syst. 2004, 82, 273-290. [CrossRef]

26. Powell, J.M.; Pearson, R.A.; Hiernaux, P.H. Crop-Livestock Interactions in the West African Drylands. Agron. J. 2004, 97, 469-483.

27. JU (Jimma University). The University Facts and Figures; Jimma University: Jimma, Ethiopia, 2006.

28. ILCA. Livestock Systems Research Manual; No. 12, Section 1, Working Document; ILCA (International Livestock Center for Africa): Addis Ababa, Ethiopia, 1990.

29. Ayana, A.; Barrs, R.M.T. The Condition of the Borena Rangelands. Livestock Production and the Environment-Implication for Sustainable Livelihoods. In Proceedings of the Seventh Annual Conference of Ethiopian Society of Animal Production (ESAP), Addis Ababa, Ethiopia, 26-27 May 1999.

30. Holechek, J.L.; Pieper, R.D.; Herbel, C.H. Range Management, Principles and Practices; Regents/Prentice Hall: Englewood Cliffs, NJ, USA, 2004.

31. Yisehak, K.; Belay, D.; Taye, T.; Geert, P.J. Impact of soil erosion associated factors on available feed resources for free-ranging cattle at three altitude regions: Measurements and perceptions. J. Arid Environ. 2013, 98, 70-78. [CrossRef]

32. Mulugeta, A. Characterization of Dairy Production Systems of Yerer watershed in Ada Liben Wereda, Oromia Region, Ethiopia. Master's Thesis, Alemaya University, Dire Dawa, Ethiopia, 2005.

33. Belay, D.; Azage, T.; Hegde, B.P. Smallholder livestock production system in Dandi district, Oromia Regional State, central Ethiopia. Glob. Vet. 2012, 8, 472-479.

34. Behnke, R.; Metaferia, F. The Contribution of Livestock to the Ethiopian Economy_Part II; IGAD Livestock Policy Initiative Working Paper No. 02-11; IGAD: Djibouti City, Djibouti, 2011.

35. Paris, T.R. Crop-animal systems in Asia: Socio-economic benefits and impacts on rural livelihoods. Agric. Syst. 2002, 71, 147-168 [CrossRef]

36. Andualem, T.; Berhan, T.; Gebeyehu, G.; Ermias, B. Characterization of cattle husbandry practices in Essera Woreda; Dawuro zone; southern Ethiopia. Afr. J. Agric. Res. 2015, 10, 3435-4321. [CrossRef]

37. CSA. Agricultural Sample Survey 2014/15 (2007 E.C.); Report on Livestock and Livestock Characteristics (Private Peasant Holdings); Central Statistical Agency (CSA): Addis Ababa, Ethiopia, 2015; Volume 2.

38. FAO. Ethiopia Report on Feed Inventory and Feed Balance 2018; Food and Agricultural Organization of the United Nations (FAO): Rome, Italy, 2018.

39. Gemiyo, D.; Hassen, A.; Kocho, T.; Birhanu, T.; Bassa, Z.; Jimma, A. Chemical composition and digestibility of major feed resources in mixed farming system of southern Ethiopia. World Appl. Sci. J. 2013, 26, 267-275.

40. Ngongoni, N.T.; Mapiye, C.; Mwale, M.; Mupeta, B. Effect of supplementing a high-protein ram press sunflower cake concentrate on smallholder milk production in Zimbabwe. Trop. Anim. Health Prod. 2007, 39, 297-307. [CrossRef] [PubMed]

41. Wambugu, C.; Place, F.; Franzel, S. Research, development and scaling-up the adoption of fodder shrub innovations in East Africa. Int. J. Agric. Sustain. 2011, 9, 100-109. [CrossRef]

42. Smith, T. Some Tools to Combat Dry Season Nutritional Stress in Ruminants under African Conditions; A Script Presented to a Workshop Organized by International Atomic Energy Agency (IAEA) in Zambia; University of Reading: Reading, UK, 2002.

43. Kabirizi, J.; Turinawe, A.; Ebiyau, G.; Kigongo, J.; Akwanga, D.; Nangooti, N. Impact of improved forage technologies on profitability of dairy enterprise and factors affecting utilisation of technologies. In Proceedings of the African Crop Science Conference, Cape Town, South Africa, 28 September-2 October 2009; pp. 745-749.

44. Assefa, F.; Ano, T.; Aba, T.; Ebrahim, Z. Assessment of improved forage types and their utilization in Shashogo Woreda; Hadiya zone; Southern Ethiopia. Glob. J. Anim. Sci. Livest. Prod. Anim. Breed. 2015, 3, 227-230. 
45. Mekasha, A.; Gerard, B.; Tesfaye, K.; Nigatu, L.; Duncan, A.J. Inter-connection between land use/land cover change and herders' / farmers' livestock feed resource management strategies: A case study from three Ethiopian eco-environments. Agric. Ecosyst. Environ. 2014, 188, 150-162. [CrossRef]

46. Moran, J. The feeding of by-products on small holder dairy farms in Asia and other tropical regions. In Asian Milk for Health and Prosperity; Asia Dairy Network; Food and Agriculture Organization: Rome, Italy, 2014.

47. Lukuyu, M.N.; Gibson, J.P.; Savage, D.B.; Duncan, A.J.; Mujibi, F.D.N.; Okeyo, A.M. Use of body linear measurements to estimate live weight of crossbred dairy cattle in smallholder farms in Kenya. SpringerPlus 2016, 5, 1-14. [CrossRef]

48. Katongole, C.B.; Nambi-Kasozi, J.; Lumu, R.; Bareeba, F.; Presto, M.; Ivarsson, E.; Lindberg, J.E. Strategies for coping with feed scarcity among urban and peri-urban livestock farmers in Kampala, Uganda. J. Agric. Rural. Dev. Trop. Subtrop. 2012, $113,165-174$.

49. Dhakal, B.; Devkota, N.R.; Upreti, C.R.; Sapkota, M. Fodder production and livestock rearing in relation to climate Change and possible adaptation measures in Manaslu Conservation area, Nepal. Int. J. Appl. Sci. Biotechnol. 2019, 7, 227-235. [CrossRef]

50. Nangula, S.; Oba, G. Effects of artificial water points on the Oshana ecosystem in Namibia. Environ. Conserv. 2004, 31, 47-54. [CrossRef]

51. Tekalign, E. Forage Seed Systems in Ethiopia: A Scoping Study; ILRI Project Report; ILRI: Addis Ababa, Ethiopia, 2014.

52. Oldeman, L.; Hakkeling, R.; Sombroek, W. World Map of the Status of Human-Induced Soil Degradation: An Explanatory Note; Global Assessment of Soil Degradation (GLASOD); International Soil Reference and Information Centre: Wageningen, The Netherlands; United Nations Environment Programme: Nairobi, Kenya, 1991.

53. Zinash, S.; Seyoum, B. Utilization of feed resources in the central zone of Ethiopia. In Proceedings of the Third National Livestock Improvement Conference, Addis Ababa, Ethiopia, 24-26 May 1989.

54. Zinash, S.; Seyoum, B.; Hailu, G.; Daniel, K. Aspects of varietal development and release in forage and pasture crops in Ethiopia. In Proceedings of the 4th National Livestock Improvement Conference of Ethiopian Society of Animal Production, Addis Ababa, Ethiopia, 18-19 April 1996.

55. Li, X.L.; Gao, J.; Brierley, G.; Qiao, Y.M.; Zhang, J.; Yang, Y.W. Grazing land Degradation on the Qinghai-Tibet Plateau: Implications for Rehabilitation. Land Degrad. Dev. 2011, 22, 193-201.

56. Devendra, C.; Sevilla, C.C. Availability and use of feed resources in crop-animal systems in Asia. Agric. Syst. 2002, 71, 59-73. [CrossRef]

57. Zewdie, W. Assessment of livestock production system and feed resources availability at Melka watershed of Nile basin, Jeldu district, Western Ethiopia. Glob. J. Sci. Front. Res. 2015, 15, 7-20. 